Daniel Bernoulli • Urs Schaltegger • Willem B. Stern • Martin Frey $\dagger \cdot$ Michèle Caron · Simonetta Monechi

\title{
Volcanic ash layers in the Upper Cretaceous of the Central Apennines and a numerical age for the early Campanian
}

Received: 25 November 2002 / Accepted: 14 December 2003 / Published online: 30 April 2004

(C) Springer-Verlag 2004

\begin{abstract}
At Montagna della Maiella and at Gola del Furlo (central Apennines) two discrete layers of bentonic clay are intercalated within the pelagic (Furlo) and turbiditic/pelagic limestones (Maiella) of the Upper Cretaceous basinal succession of the Umbrian basin (Scaglia facies). The bentonite layers are dated by planktonic foraminifera to the Globotruncanita elevata zone, early Campanian, and by calcareous nannofossils to the Aspidolithus parcus zone (CC 18); they fall into the reversed interval of chron 33. Detailed correlation shows the layers to be of exactly the same age. The upper layer is dated by $\mathrm{U} / \mathrm{Pb}$ on magmatic zircons to $81.67 \pm 0.21 \mathrm{Ma}$, an age compatible with the Cretaceous time-scale of Obradovich. The mineralogy of the bentonitic clays is almost pure montmorillonite and contrasts sharply with the clay mineral assemblage of the enclosing pelagic and turbiditic limestones, which is dominated by soil-derived smectite and illite in different proportions. The bentonite seams are interpreted as the submarine alteration products of wind-borne volcanic ashes. They can be followed with only minor changes in thickness over $200 \mathrm{~km}$ and must be derived from distant volcanic sources and related to extreme volcanic events. A possible source area is present in the Di-
\end{abstract}

D. Bernoulli $(\bullet) \cdot$ W. B. Stern · M. Frey $\dagger$

Department of Earth Sciences,

University of Basel,

Bernoullistrasse 32, 4056 Basel, Switzerland

e-mail: daniel.bernoulli@unibas.ch

U. Schaltegger

Department of Mineralogy,

University of Geneva,

Rue des Maraîchers, 1205 Genève, Switzerland

M. Caron

Department of Earth Sciences,

University of Fribourg,

Pérolles, 1700 Fribourg, Switzerland

S. Monechi

Dipartimento di Scienze della Terra,

Università degli Studi,

Via La Pira 4, 50121 Firenze, Italy narides where Upper Cretaceous subduction-related magmatic rocks are widespread.

Keywords Apennines - Bentonite - Biostratigraphy · Geochronology $\cdot \mathrm{U} / \mathrm{Pb}$ age $\cdot$ Zircon

\section{Introduction}

The mineralogical, chemical and isotopic signatures preserved in continuously deposited pelagic sediments document changes in global material cycling. In the central Mediterranean area, pelagic sediments deposited on the deeply submerged southern continental margin of the Jurassic-Cretaceous Tethys Ocean represent an excellent geological archive for the reconstruction of the palaeooceanographic evolution. Whereas C-isotope stratigraphy records perturbations in the global carbon cycle (e.g. Weissert 1989; Jenkyns et al. 1994, 2002), clay mineral assemblages reflect conditions of soil evolution on continental areas and exposed carbonate platforms in response to regional climatic changes and tectonic events (e.g. Deconinck and Bernoulli 1991; Deconinck 1992). At times, however, the pelagic record is punctuated by volcanic events, which are documented by ash layers, occurring today as relatively thin bentonitic clays seams (e.g. Bernoulli and Peters 1970, 1974). Such proxies of explosive, often subduction-related volcanicity appear to be relatively scarce in the external zones of the periAdriatic orogens or, in many cases, may not have been recognised as such. They may indicate, however, volcanic activity that is important for the reconstruction of the geodynamic evolution of the Tethyan margins.

In this paper, we document the occurrence of two altered, smectitic ash layers in the Upper Cretaceous (lower Campanian) of the external Apennines and discuss their significance and possible origin. The volcanic ash layers are intercalated in the pelagic limestones of the Upper Cretaceous-Palaeogene (Turonian to Eocene) Scaglia Rossa Formation or its lateral equivalent, the Tre Grotte Formation (Turonian to Campanian), and can be safely 


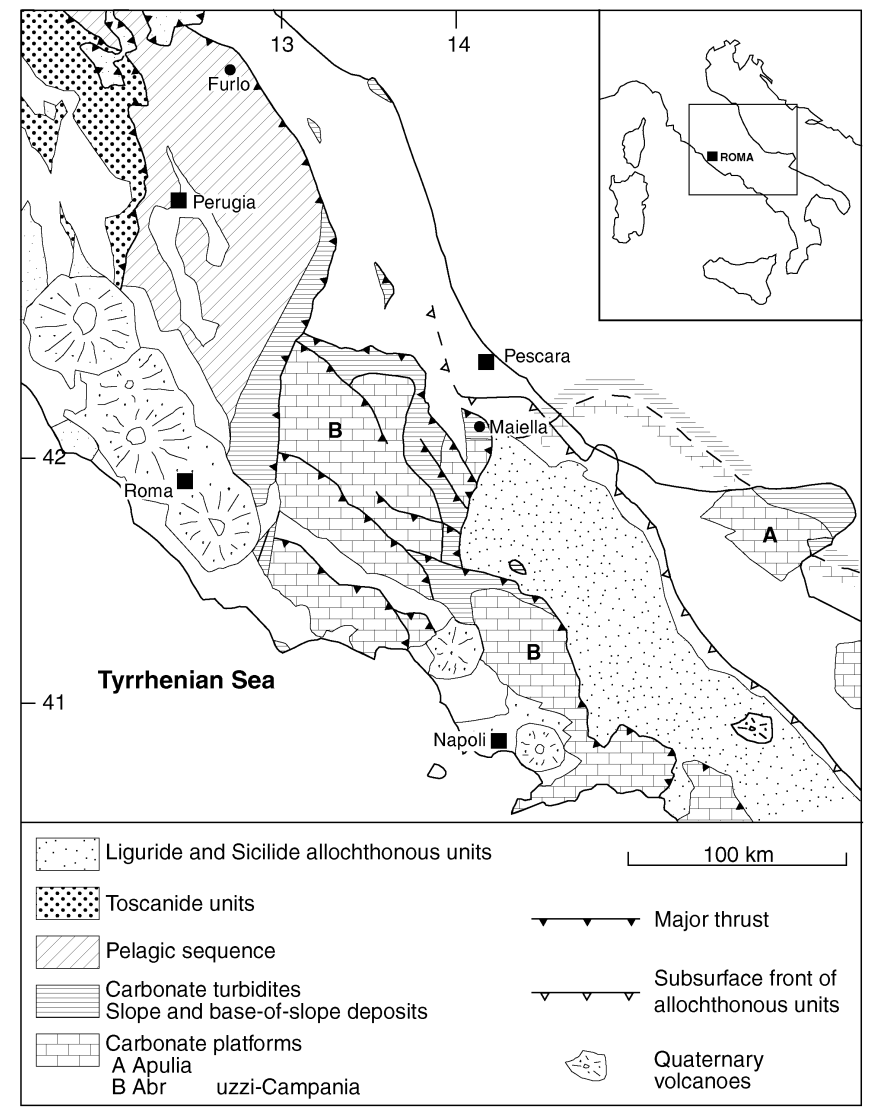

Fig. 1 Location of Montagna della Maiella and Furlo in their tectonic and Cretaceous palaeogeographic frame

correlated over $200 \mathrm{~km}$ between Montagna della Maiella in the south to Furlo in the north (Fig. 1). Biostratigraphic and palaeomagnetic age determinations are consistent, and dating by $\mathrm{U}-\mathrm{Pb}$ of zircons allows us to attribute a numerical age to the early Campanian Globotruncanita elevata and the Aspidolithus parcus (CC 18) zones.

The late Cretaceous time scale has essentially been developed from numerical ages in the Western Interior Basin of North America (Obradovich 1993), whereas numerical ages from European localities are very scarce. Our data calibrate, with high precision, the age of the early Campanian Globotruncanita elevata zone; they are compatible with and thus confirm the time scale of Obradovich (1993). They further document late Cretaceous explosive volcanicity most probably related to subduction in the internal Dinarides. We suspect that similar traces of explosive volcanicity related to late Mesozoic-Palaeogene subduction in the Alpine-Mediterranean chains might have been overlooked in many cases and might be much more numerous than hitherto recognised. If this is the case, there exists a potential for establishing a high-precision chronology of the pelagic Tethyan successions.

\section{Geologic setting and occurrence of ash layers}

The external zone of the central Apennines is part of a fold-and-thrust belt, built up by Mesozoic and Cenozoic sedimentary rocks that were detached along Upper Triassic evaporites from their original basement, which consists of Palaeozoic sediments and continental crust (Bally et al. 1986; Mostardini and Merlini 1988). During Mesozoic times, the area was part of the Adriatic margin of the Liguria-Piemonte segment of the Alpine Tethys. After partial drowning of a late Triassic-early Liassic carbonate bank, the area was occupied by isolated, Bahamian-type carbonate platforms interspersed with deeper basins of pelagic sedimentation, which lasted into the early Tertiary and locally into the middle Miocene (e.g. Bernoulli 2001). The volcanic ash layers we describe are intercalated in basinal deposits, pelagic limestones of the so-called Scaglia facies. In the northern part of the area, in the Apennines of the Umbria and Marche regions, these limestones, which range from Cenomanian to late Eocene, are typically pelagic (e.g. Montanari et al. 1989). To the south and east they interfinger with turbidites and other mass-flow deposits derived from the surrounding carbonate platforms (e.g. Vecsei et al. 1998; van Konijnenburg et al. 1999).

Montagna della Maiella

In Montagna della Maiella, the east-west-trending margin of a Mesozoic-early Tertiary Bahamian-type carbonate platform is exposed in the north-south trending frontal anticline of one of the thrust sheets of the external Apennines (Fig. 1; Ghisetti and Vezzani 1983; Mostardini and Merlini 1988). During most of the late Cretaceous, the platform was bordered to the north by a steep, nondepositional escarpment (Crescenti et al. 1969; Accarie 1988; Eberli et al. 1993), which was inherited from early Jurassic rifting and is morphologically very similar to the buried escarpments below Great Bahama Bank (Eberli et al. 2004). A 900-m-thick Upper Cretaceous succession of pelagic/peri-platform chalks and limestones, carbonate turbidites and megabreccias onlaps the escarpment (Tre Grotte Formation, Vecsei 1991; Supersequence 1 of Eberli et al. 1993). This lithological assemblage is conspicuously similar to sequences deposited during the same time interval in the deep-water sea-ways of the Bahamian archipelago (e.g. Northwest Providence Channel, Bernoulli 1972). In the late Campanian to early Maastrichtian, the deep-water sediments buried the escarpment, and shallower facies prograded over the former basin margin (Mutti et al. 1996). From latest Cretaceous to Oligocene times, the depositional history of the Maiella was characterised by two major phases of progradation on a distally steepened ramp before the installation of a gently inclined shelf in latest Oligocene to Miocene times (Vecsei et al. 1998). The late Miocene desiccation of the Mediterranean interrupted carbonate deposition before the area was involved in thrusting and folding during the Pliocene. 

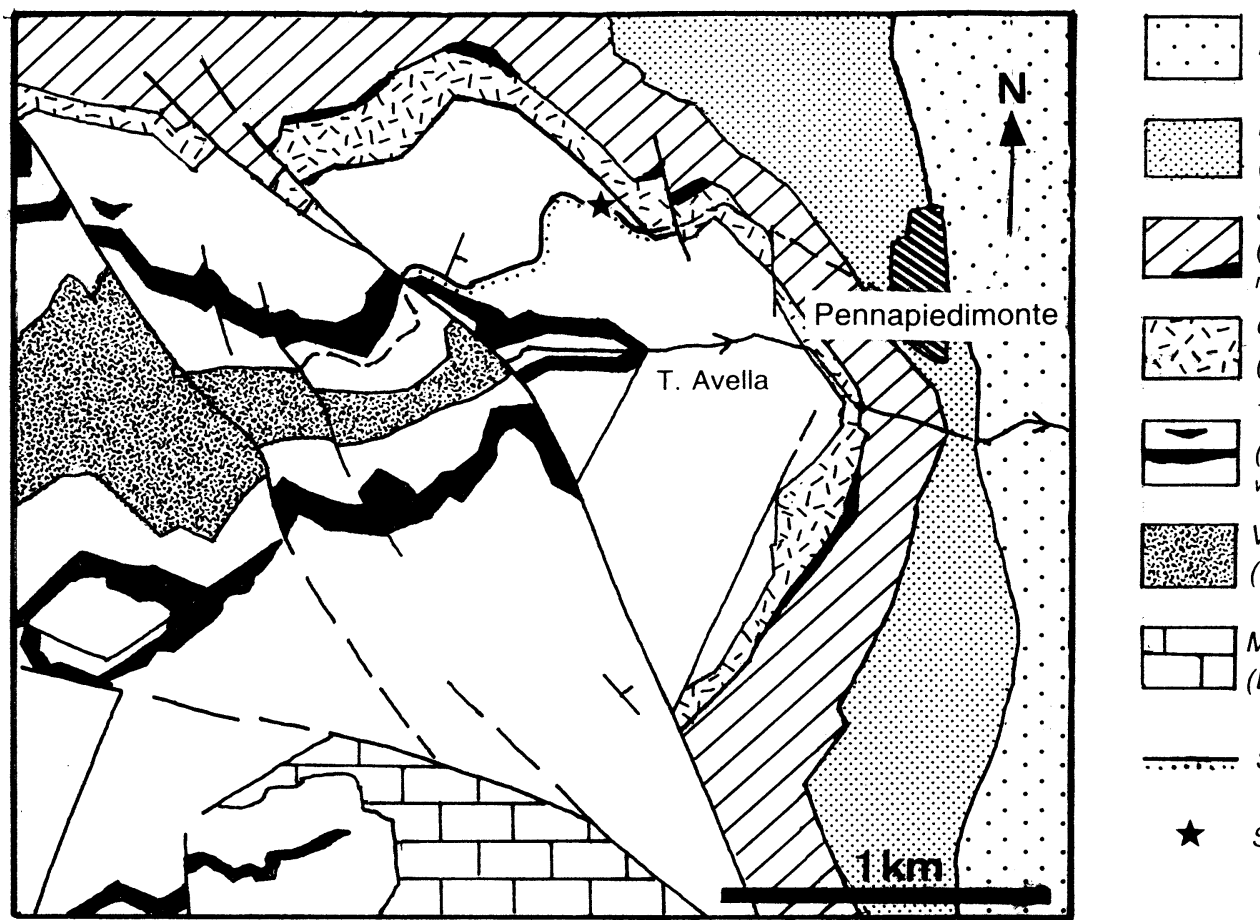

Pliocene and Quaternary formations

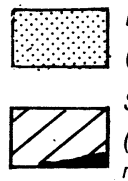

Bolognano Formation

(Upper Oligocene p.p. - Miocene)

Santo Spirito Formation

(Paleocene-Eocene)
megabreccias

1:- Orfento Formation

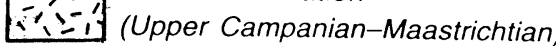

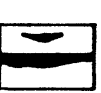

Tre Grotte Formation

(Turonian-middle Campanian)

with megabreccias

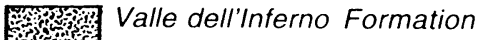

5.

\begin{tabular}{|l} 
Morrone del Pacentro Formation \\
\hline \\
\hline
\end{tabular}

S.... Section Fig. $3 b$

$\star$ Section Fig. 4

Fig. 2 Geological sketch map of Valle Tre Grotte (after Accarie 1988) and location of section

The volcanic ash layers we describe are intercalated in the Upper Cretaceous (Turonian to lower Campanian) Tre Grotte Formation in Valle Tre Grotte west of the village of Pennapiedimonte (province of Chieti) where a more or less continuous section that is cut by a few faults is observed (Figs. 2 and 3; Accarie 1988; Vecsei 1991; Lampert et al. 1997). The small section illustrated in Fig. 4 is situated along the dust road leading from Pennapiedimonte into Valle Tre Grotte (for location see Fig. 2; Carta d'Italia 1:25,000, tavoletta Pennapiedimonte [ [F 147 III NE] , Carta Geologica d'Italia, 1:100,000, $\mathrm{F}^{\mathrm{o}}$ 147: Lanciano 1970). The host formation consists of white pelagic/ peri-platform chalks and limestones, rich in planktonic foraminifera (typical Scaglia facies of Italian authors) with intercalated $\mathrm{cm}$ - to dm-thick bioclastic turbidites derived from the margin of the adjacent carbonate platform. Nodules and bands of red chert are of early diagenetic replacement origin. Down-section, up to several tens of metres-thick megabreccias, also derived from the platform, are intercalated (Figs. 2 and 3; Accarie 1988; Vecsei 1991; Eberli et al. 1993).

The volcanic ash layers occur as 13- to 15-cm (upper layer, Figs. 4 and 5) and 4-to 5-cm-thick (lower layer) intercalations of yellowish-orange and greenish grey bentonitic plastic clay, which can be followed over the length of the outcrop. The lower and upper contacts are sharp and there is no visible evidence of burrowing along the top of the layers. Locally, the base of the upper layer is white and appears to be slightly coarser; however, there is no evidence of redistribution by currents or gravitational processes. A similar bentonite, only $1-2 \mathrm{~cm}$ thick occurs about $11 \mathrm{~m}$ above the upper bentonite layer. Until now, no volcanic ash layers were found on the adjacent platform.

\section{Gola del Furlo}

The mountain range Monte Pietralata-Monte Paganuccio is another frontal anticline in the fold-and-thrust belt of the external Apennines. Gola del Furlo, a deep canyon across the anticline, exposes a continuous section from the lower Liassic carbonate platform to the Tertiary pelagic and hemipelagic deposits. The sequence belongs to one of the Jurassic seamounts, on which a condensed Jurassic succession of pelagic limestones overlies a submerged fault block inherited from Jurassic rifting (cf. Bernoulli et al. 1979; Bice and Stewart 1990). The Lower Cretaceous succession consists of pelagic limestones of the Maiolica Formation (uppermost Jurassic to Barremian), hemipelagic marls and marly limestones of the Marne a Fucoidi Formation (Aptian-Albian), which, at Furlo, are thinner than elsewhere (Alvarez and Lowrie 1984). The pelagic limestones of the Scaglia Bianca (Cenomanian) and Scaglia Rossa Formation (Turonian to Eocene) generally lack redeposited strata, but, at Furlo, they include, in their lower part (Cenomanian to Coniacian), several slump complexes in which the stratigraphic succession is locally repeated and, in their upper part (Coniacian to Paleocene), white calcarenitic turbidites derived from a shallow-water area (Fig. 3; Alvarez and Lowrie 1984). These deposits suggest ongoing synsedimentary tectonic movements (Montanari et al. 1989) and/ or persisting sub-marine topography inherited from rifting 
Fig. 3 Magneto- and lithostratigraphy of the sections at Furlo (after Alvarez and Lowrie 1984) and in Valle Tre Grotte (Montagna della Maiella, after Lampert et al. 1997) and planktonic foraminiferal zonation. Asterisks mark the stratigraphic position of the ash layers. SSB Supersequence boundary

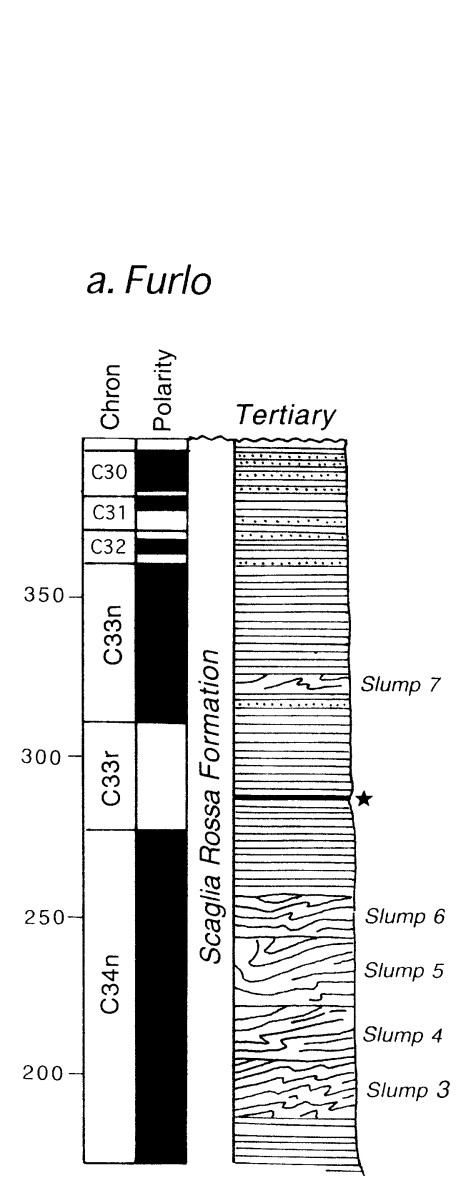

\section{b. Montagna della Maiella}

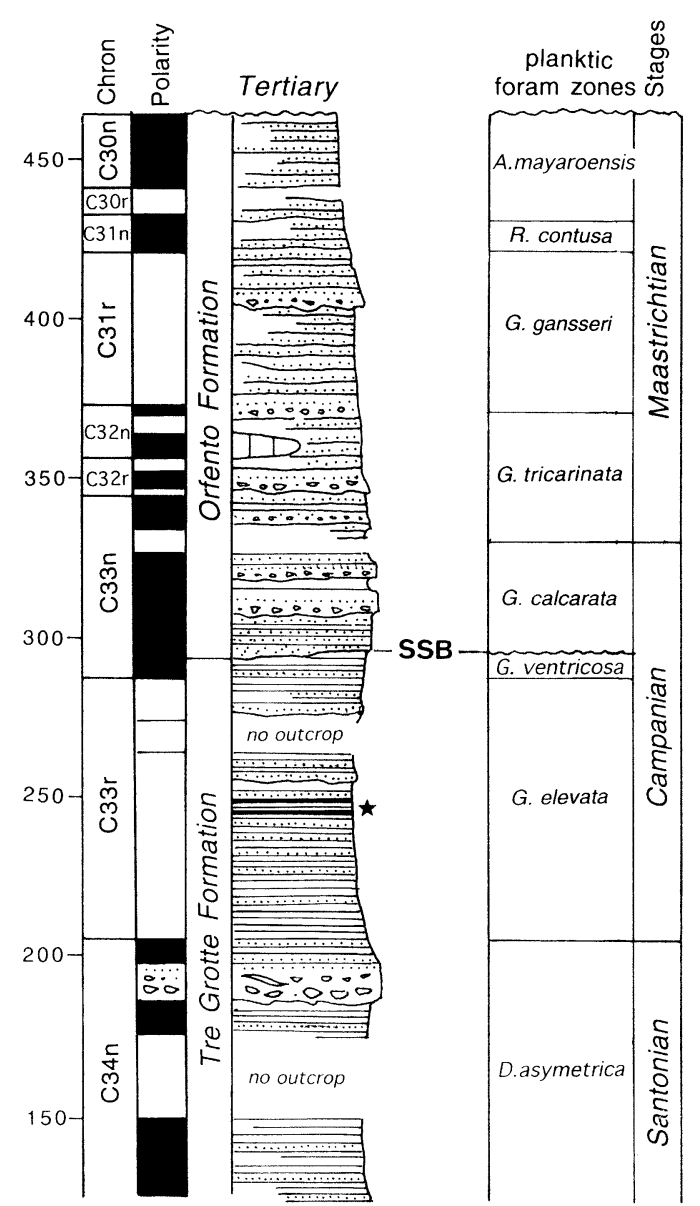

and accentuated by differential compaction of the basinal sediments.

At Furlo, as at Montagna della Maiella, two bentonitic clay layers are intercalated in the Scaglia Rossa Formation (Fig. 4; Carta d'Italia 1:25,000, tavoletta Monte Paganuccio [ $\left.\mathrm{F}^{\mathrm{O}} 116 \mathrm{I} \mathrm{NO}\right]$; Carta Geologica d'Italia, 1:100,000, $\mathrm{F}^{\mathrm{O}}$ 116: Gubbio 1952). The upper layer, $15 \mathrm{~cm}$ thick (Fig. 6), has been described by Mattias et al. (1988); the lower layer, only $3 \mathrm{~cm}$ thick, has not been observed before. We measured and sampled both horizons at locality 1 of Mattias et al. (1988) above the Flaminia Road and at locality 2, the so-called Furlo Upper Road of Alvarez and Lowrie (1984; for exact locations see Mattias et al., their Figs. 1-4).

\section{Methods}

Mineralogy

For the determination of clay minerals, limestone samples were ground in a tungsten carbide disk mill for $30 \mathrm{~s}$. The soft volcanic ash layers needed no grinding. Carbonate was removed by treatment with acetic acid (5\%) and repeated washing. The removal of carbonate was not complete in specimen F15 (possibly because of enveloping clay minerals). The grain size fraction $<2 \mu \mathrm{m}$ was extracted by using differential settling tubes and Millipore filters. No cation saturation was performed, but it is assumed that acid dissolution of calcite resulted in $\mathrm{Ca}$ saturation. X-ray glass mounts were prepared by sedimentation. X-ray diffractograms were first performed on air-dried separates, and then on glycolated ones. All runs were performed with a Siemens/Bruker/AXS diffractometer (D-5000, Cu radiation $40 \mathrm{kV}, 30 \mathrm{~mA}$; secondary graphite monochromator; automatic divergence and antiscatter slits; Diffracplus software by Socabim).

Chemical analysis of clay minerals were obtained by energy-dispersive X-ray spectrometry (ED-XFA, X-Lab 2000 of Spectro Germany, routine FOIL2001) with microspecimens on police tape, and by combustion analysis (Leco RC-412, dynamic mode) for $\mathrm{C}, \mathrm{CO}_{2}$ and $\mathrm{H}_{2} \mathrm{O}$ determination. For technical details see Stern et al. (1991, their Table 3) and Petrova et al. (2002). Our results are given in Table 1.

Freshly broken sediment and rock surfaces were goldsputter coated and investigated with a stereoscan electron microscope (Philips ESEM XL 30 FEG) with an attached energy dispersive analyser (EDAX). 

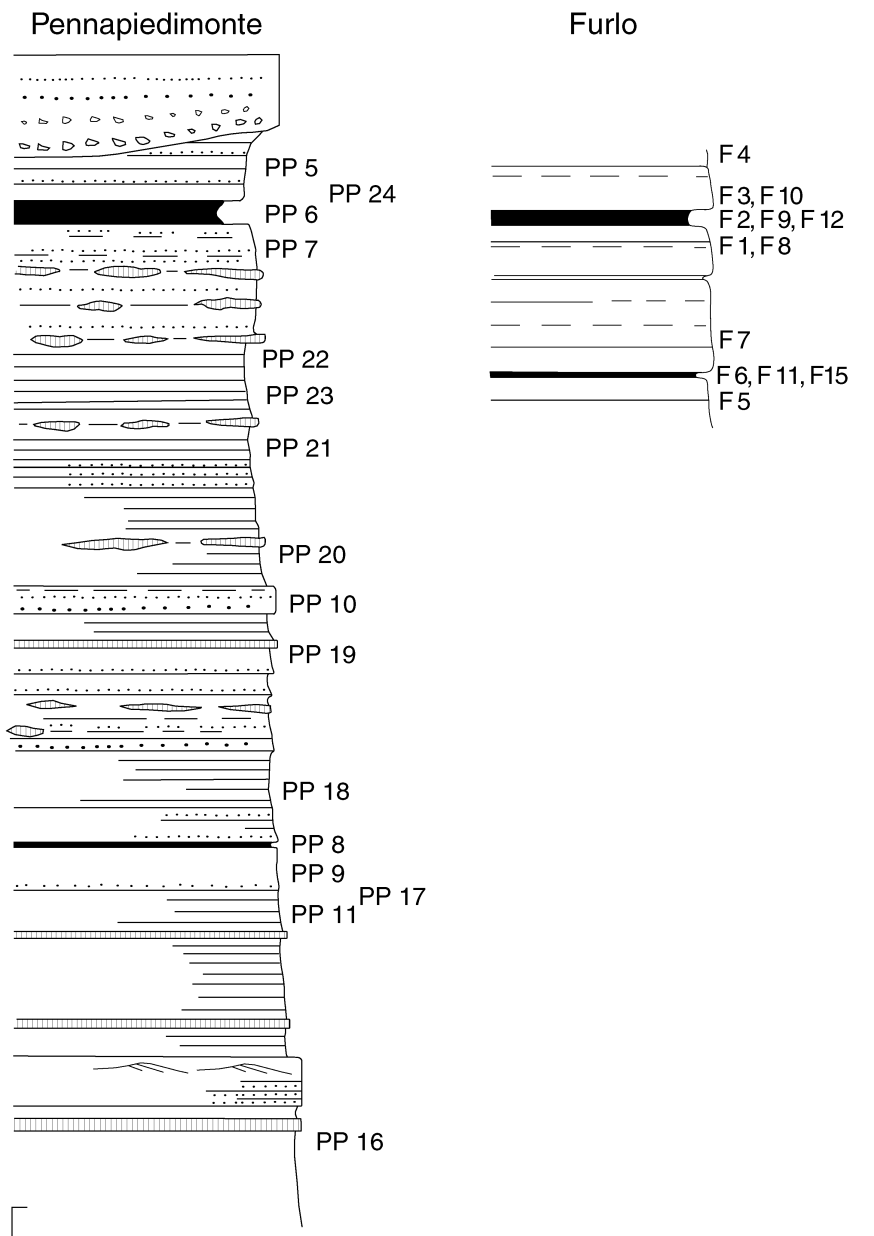

$1 \mathrm{~m}$

Fig. 4 Detailed section with lower Campanian volcanic ash layers, Tre Grotte Formation, Valle Tre Grotte, Montagna della Maiella and Scaglia Rossa Formation, Furlo

For the determination of the heavy minerals, the samples were crushed in a mortar and disaggregated by repeated application of Désogen (Ciba-Geigy, 5\% solution). After decantation of the clay fraction and drying, carbonate was removed by treatment with cold $10 \%$ acetic acid. Cold $\mathrm{H}_{2} \mathrm{O}_{2}$ was applied to destroy organic matter. Ultrasonic treatment was applied during several stages of sample preparation. The heavy minerals were separated by bromoforme $(\rho=2.9)$ in a separation funnel. The heavy mineral fraction was mounted in piperine $(n=1.68)$ and quantified under the petrographic microscope by ribbon counting. Results are given as frequency percents (Table 2).

\section{Biostratigraphy}

Fourteen samples from above and below the bentonite seams at Pennapiedimonte and at Furlo were analysed for their calcareous nannofossil assemblages. Smear slides

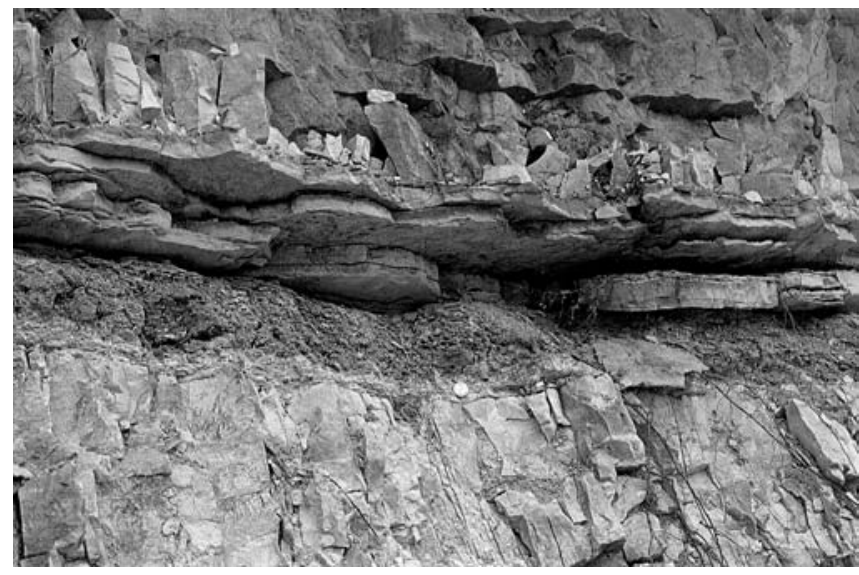

Fig. 5 Upper ash layer $(13-15 \mathrm{~cm})$ intercalated between laminated and redeposited fine calcarenites with lenses of diagenetic replacement chert (below) and fine calcarenites and pelagic limestones (above). Valle Tre Grotte, Montagna della Maiella. Scale: small coin below ash layer is $2 \mathrm{~cm}$ across

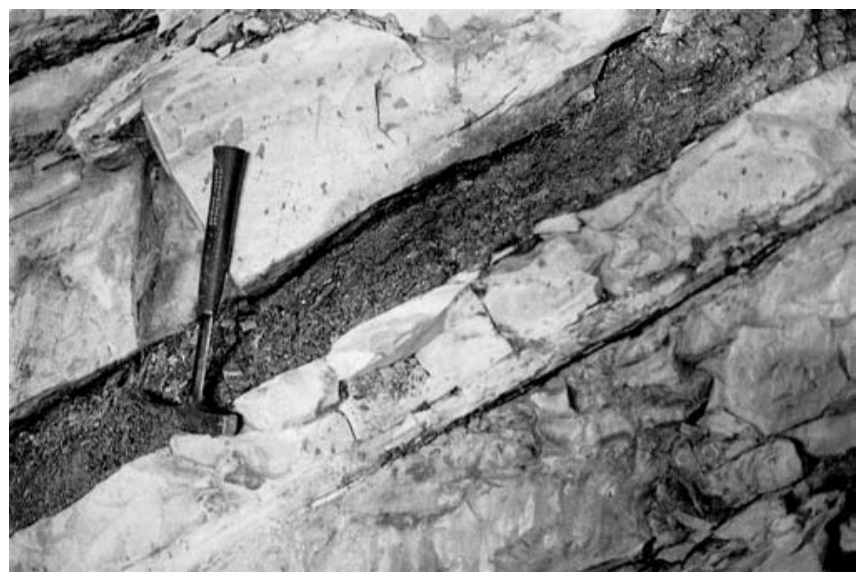

Fig. 6 Upper ash layer $(15 \mathrm{~cm})$ intercalated between pelagic limestones. Furlo, locality 1 of Mattias et al. (1988)

were prepared according to standard methods and analysed with a petrographic microscope at magnification $\mathrm{x} 1,500$. The planktonic foraminifera were determined in thin-section.

\section{$\mathrm{U}-\mathrm{Pb}$ zircon dating}

Volcanic zircons have been analysed from the inferred ash layers PP-6 from the Pennapiedimonte section, and F2 of the Furlo section (see Fig. 4). The zircons were extracted from the bentonite samples using standard techniques and the least magnetic fraction was collected on a Frantz magnetic separator. A further selection of inclusion- and crack-free zircons was abraded in order to remove marginal zones of lead loss. After cleaning in $4 \mathrm{~N}$ $\mathrm{HNO}_{3}$ and thorough rinsing with water and acetone in an ultrasonic bath, the zircons were spiked with a mixed ${ }^{205} \mathrm{~Pb}-{ }^{235} \mathrm{U}$ tracer solution and dissolved in $\mathrm{HF}-\mathrm{HNO}_{3}$. 
Fig. 7 a Profile Pennapiedimonte (Montagna della Maiella). Upper $(P P$ G) and lower (PP 8) bentonite (volcanic ash) layers. X-ray diffractograms, air-dried clay fractions (solid lines) with vertical bars indicating montmorillonite from the ICDD data bank (no. 2-0014), and runs of the same separates after glycolation (crosses). The shift towards lower diffraction angles, and hence higher d-values by glycolation is clearly visible. No other mineral phases are detectable besides montmorillonite/smectite; b Profile Furlo, Upper ( $F$ 9) and lower (F 15) bentonite (volcanic ash) layers. X-ray diffractograms in analogy to a. The prevalent mineral is again montmorillonite/smectite; in F-15 calcite is still present (roughly $25 \mathrm{wt} \%$, but not visible in the shown angular range) and probably illite as an additional minor phase
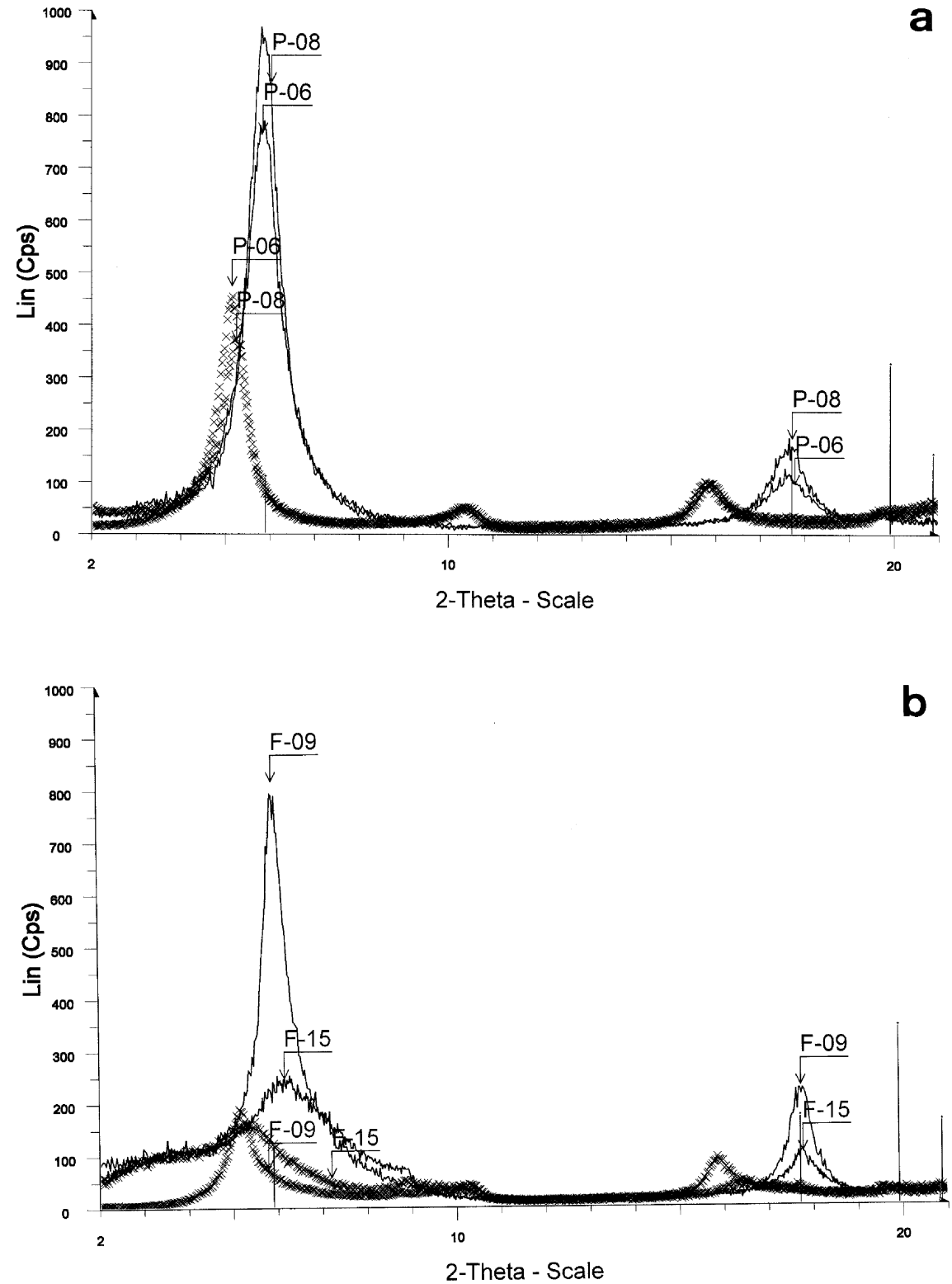

After chemical extraction, $\mathrm{Pb}$ and $\mathrm{U}$ were loaded with $\mathrm{Si}-\mathrm{Gel}$ onto a Re filament, their isotopic composition being analysed using an ion counting system mounted on a MAT 262 mass spectrometer. The performance of the ion counting system was monitored by repeated analyses of a NBS 982 standard solution. Common lead in excess of the blank was corrected using the crustal model of Stacey and Kramers (1975). Total procedural blanks were estimated at $1 \pm 0.5 \mathrm{pg}$ of $\mathrm{Pb}$. Isotopic ratios and corresponding apparent ages are given in Table 3.

\section{Results}

\section{Mineralogy}

The clay fraction of both bentonite layers and of the limestones is dominated by smectite-montmorillonite.
The diffractogram is characterized by a succession of basal reflections at 14.7, 5.0 and $3.0 \AA$ in the air-dried state and at 16.7 to $17.0,8.5$ to $8.7,5.5$ to $5.6,4.2 \AA$ in the glycolated state (Fig. 7a, b). The limestone samples contain in addition minor amounts of illite and quartz. The degree of ordering of the smectite-montmorillonite varies with the lowest ordering in sample F-15 (broadest reflection, highest background).

The chemical composition of the clay fraction of the two bentonite layers is in agreement with the crystallographic information obtained from the diffraction data and given in Table 1. Probably because of the extremely fine grain size of the bentonites, acid treatment did not dissolve entirely the calcite present (F-15), and washing did not succeed in complete removal of calcium as the chemical analysis of the clay fraction shows (Table 1). An excess of calcium was assumed and the $\mathrm{CaO}$ content recalculated to $2 \mathrm{wt} \%$ in accordance with Newman (1987, 
Table 1 Chemical analyses of Upper Cretaceous bentonites, Montagna della Maiella and Furlo
Table 2 Heavy mineral assemblages from Upper Cretaceous bentonites, Montagna della Maiella and Furlo

\begin{tabular}{|c|c|c|c|c|c|c|c|c|c|}
\hline \multirow[b]{3}{*}{ Samples } & \multicolumn{9}{|c|}{$\mathrm{CaO}$ normalized to $2.0 \mathrm{wt} \%$} \\
\hline & \multicolumn{4}{|l|}{ wt $\%$} & \multicolumn{5}{|c|}{ Structural formula (22 O) } \\
\hline & \multicolumn{2}{|l|}{ PP 06} & F 09 & \multicolumn{2}{|l|}{ F 15} & PP 06 & PP 08 & F 09 & F 15 \\
\hline $\mathrm{SiO}_{2}$ & 49.02 & 48.32 & 46.92 & 46.13 & si & 7.66 & 7.51 & 7.21 & 7.03 \\
\hline $\mathrm{TiO}_{2}$ & 0.49 & 0.65 & 0.55 & 0.81 & $\mathrm{ti}$ & 0.06 & 0.08 & 0.06 & 0.09 \\
\hline $\mathrm{Al}_{2} \mathrm{O}_{3}$ & 14.24 & 14.51 & 15.85 & 15.41 & al & 2.62 & 2.66 & 2.87 & 2.77 \\
\hline $\mathrm{Fe}_{2} \mathrm{O}_{3}$ & 6.05 & 6.99 & 9.58 & 11.64 & fe & 0.71 & 0.82 & 1.11 & 1.33 \\
\hline $\mathrm{MgO}$ & 4.64 & 4.80 & 3.60 & 3.34 & $\mathrm{mg}$ & 1.08 & 1.11 & 0.82 & 0.76 \\
\hline $\mathrm{CaO}$ & 2.00 & 2.00 & 2.00 & 2.00 & $\mathrm{ca}$ & 0.33 & 0.33 & 0.33 & 0.33 \\
\hline $\mathrm{Na}_{2} \mathrm{O}$ & 0.41 & 0.42 & 0.00 & 0.38 & na & 0.13 & 0.13 & 0.00 & 0.11 \\
\hline $\mathrm{K}_{2} \mathrm{O}$ & 0.85 & 1.13 & 3.33 & 4.80 & $\mathrm{k}$ & 0.17 & 0.22 & 0.65 & 0.93 \\
\hline $\mathrm{H}_{2} \mathrm{O}$ & 21.70 & 20.90 & 17.70 & 14.40 & tetr & 8.00 & 8.00 & 8.00 & 8.00 \\
\hline & & & & & oct & 4.13 & 4.17 & 4.08 & 3.98 \\
\hline & & & & & alk & 0.63 & 0.68 & 0.98 & 1.37 \\
\hline Sum & 99.40 & 99.71 & 99.52 & 98.90 & & & & & \\
\hline & Origin: & data frol & $\mathrm{n}$ ED-XF & Police tape & X-La & ab 2000 & & & \\
\hline Samples & PP 06 & PP 08 & F 09 & F 15 & & PP 06 & PP 08 & F 09 & F 15 \\
\hline $\mathrm{SiO}_{2}$ & 47.50 & 46.30 & 45.60 & 42.80 & si & 7.51 & 7.31 & 7.08 & 6.69 \\
\hline $\mathrm{TiO}_{2}$ & 0.47 & 0.62 & 0.53 & 0.75 & $\mathrm{ti}$ & 0.06 & 0.07 & 0.06 & 0.09 \\
\hline $\mathrm{Al}_{2} \mathrm{O}_{3}$ & 13.80 & 13.90 & 15.40 & 14.30 & al & 2.57 & 2.59 & 2.82 & 2.64 \\
\hline $\mathrm{Fe}_{2} \mathrm{O}_{3}$ & 5.86 & 6.70 & 9.31 & 10.80 & fe & 0.70 & 0.80 & 1.09 & 1.27 \\
\hline $\mathrm{MgO}$ & 4.50 & 4.60 & 3.50 & 3.10 & $\mathrm{mg}$ & 1.06 & 1.08 & 0.81 & 0.72 \\
\hline $\mathrm{CaO}$ & 4.41 & 5.30 & 4.30 & 8.10 & $\mathrm{ca}$ & 0.75 & 0.90 & 0.72 & 1.36 \\
\hline $\mathrm{Na}_{2} \mathrm{O}$ & 0.40 & 0.40 & 0.00 & 0.35 & na & 0.12 & 0.12 & 0.00 & 0.11 \\
\hline $\mathrm{K}_{2} \mathrm{O}$ & 0.82 & 1.08 & 3.24 & 4.45 & $\mathrm{k}$ & 0.17 & 0.22 & 0.64 & 0.89 \\
\hline $\mathrm{H}_{2} \mathrm{O}$ & 21.70 & 20.90 & 17.70 & 14.40 & tetr & 8.00 & 8.00 & 8.00 & 8.00 \\
\hline & & & & & oct & 3.90 & 3.85 & 3.86 & 3.41 \\
\hline Sum & 99.46 & 99.80 & 99.58 & 99.05 & alk & 1.04 & 1.24 & 1.36 & 2.35 \\
\hline Sample & PP & & & F 2 & & & F 6 & & \\
\hline & & r bentor & & Upper 1 & bentor & nite & Lower & benton & nite \\
\hline & & & & Furlo & & & Furlo & & \\
\hline & & & requency & Counts & & Frequency & Counts & & Frequency \\
\hline & & & $\%)$ & & & $(\%)$ & & & $\%)$ \\
\hline Garnet & 4 & & 17.9 & 37 & & 35.9 & 12 & & 10.3 \\
\hline Tourmaline & & & 2.4 & 8 & & 7.8 & 3 & & 2.6 \\
\hline Zircon & 11 & & 45.6 & 38 & & 36.9 & 29 & & 25.0 \\
\hline Rutile & 1 & & 4.0 & 2 & & 1.9 & 1 & & 0.9 \\
\hline Brookite & & & 2.4 & 1 & & 1.0 & & & \\
\hline Anatas & & & 2.4 & & & & & & \\
\hline Monacite & & & & 3 & & 2.9 & & & \\
\hline Titanite & & & 2.8 & & & & & & \\
\hline Apatite & 2 & & 10.3 & 13 & & 12.6 & 71 & & 61.2 \\
\hline Kaersutite & & & 2.0 & & & & & & \\
\hline Sum & 22 & & 00 & 103 & & 100 & 116 & & 100 \\
\hline
\end{tabular}

Table 1.16). According to their structural formula, the smectites are dioctahedral and close to the end-member montmorillonite (Table 1).

In stereoscan electron micrographs, individual grains with vacuoles, resembling glass shards and coated by clay minerals, can be recognized in the white clay at the base of the ash beds (PP 6, Maiella, Fig. 8b). These grains coalesce (Fig. 8c) and in the upper, greenish grey or reddish part of the bed a dense mass of crenulated to flaky smectite is present that morphologically resembles smectite from other bentonitic clays (Fig. 8d, compare e.g. Welton 1984; Laviano and Melidoro 1994, their Fig. 5).

The heavy mineral fractions of the ash layers consists of about 30 to $35 \%$ transparent mineral grains and $65-$
$70 \%$ of opaque minerals (visual estimate). Opaques are mainly iron oxide grains of irregular shape. The composition of the transparent mineral assemblage is given in Table 2. In the upper ash layer, the most frequent heavy mineral is zircon (45.6\% [Maiella] and 36.9\% [Furlo]), followed by garnet, apatite, tourmaline and Ti-oxides with minor monacite at Furlo. Titanite, kaersutite and epidote are subordinate. At Montagna della Maiella, more than half $(53 \%)$ of the zircon grains are euhedral, very transparent and with very sharp edges, in part these are needles, but also short-prismatic and platy crystals are observed. At Furlo, rounded zircon grains are more frequent $(62 \%)$. At Furlo, the heavy mineral assemblage of the lower ash layer is dominated by apatite $(61 \%)$, followed 


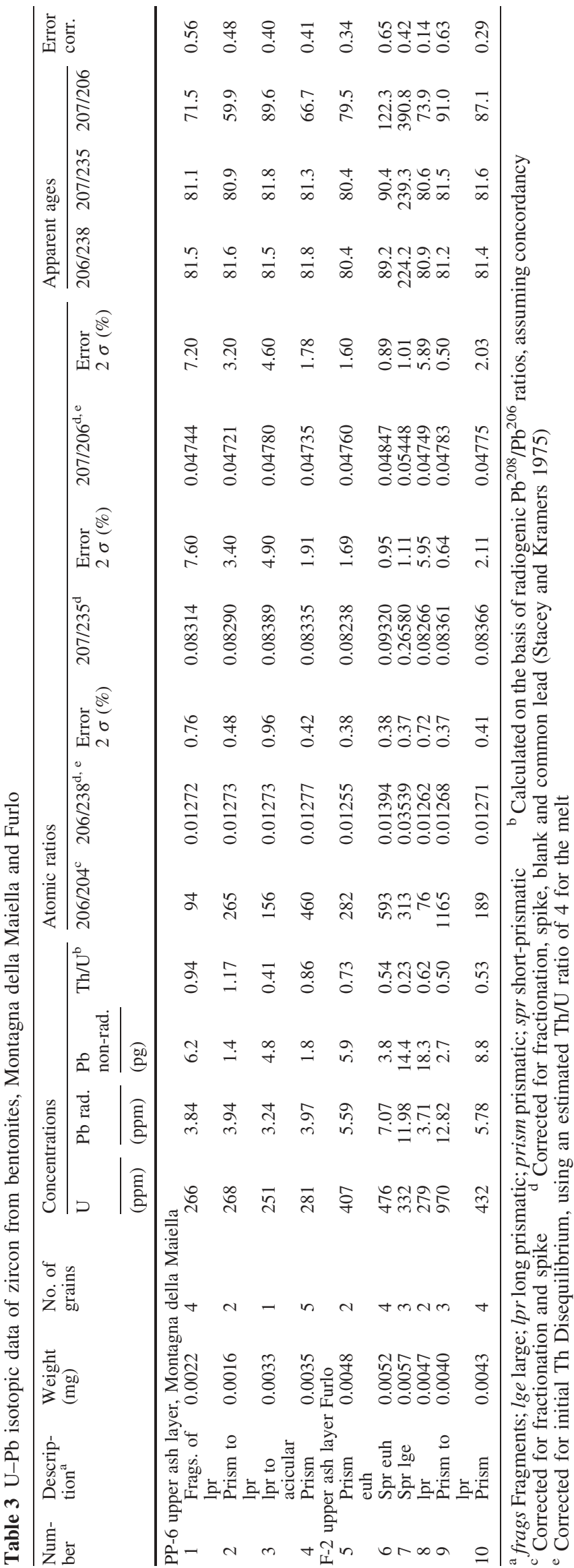

by zircon (25\%), garnet (10\%) and minor amounts of tourmaline and rutile. The zircon grains are mostly euhedral needles (74\%), but rounded grains occur as well.

Biostratigraphy

Planktonic foraminifera

The foraminiferal associations that occur below and above the bentonite seams at Pennapiedimonte are characteristic for the early Campanian Globotruncanita elevata zone. Sample PP 7 (Fig. 9f-h), contains Rosita fornicata, Rosita cf. patelliformis, Globotruncana linneiana, Globotruncana bulloides, Globotruncanita elevata, Globotruncanita stuartiformis and Marginotruncana sigali. Sample 250.30A (Fig. 9a-e) contains a large number of G. elevata, associated with G. stuartiformis, Globo-truncana arca and Marginotruncana pseudolinneiana. The rare specimens allocated to Marginotruncana (sigali, pseudolinneiana) are considered to be 'survivors' from Santonian time because they have been reported up to the early Campanian in other areas, including the Bottaccione section (Gubbio) $200 \mathrm{~km}$ to the north (Premoli Silva and Sliter 1994). Therefore, we do not consider these fossils to be reworked. The occurrence of Globotruncanita elevata and G. stuartiformis, associated with Globotruncana linneiana and G. arca, together with the absence of Dicarinella asymetrica, confirm the Globotruncanita elevata biozone of the early Campanian (Robaszynski and Caron 1995).

\section{Calcareous nannofossils}

The calcareous nannofossil assemblages from Pennapiedimonte and Furlo are abundant and diversified, their state of preservation ranges from medium to poor. The assemblages are all characteristic for the early Campanian and include the following species (Fig. 10c-t: Aspidolithus parcus parcus, A. parcus constrictus, Chiastozygus litterarius, Cretarhabdus conicus, Cribro-sphaerella ehrenbergi, Cylindralithus serratus, Eiffellithus turrisseiffelii, Eiffellithus eximius, Lucianorhabdus cayuexii, Manivitella pemmatoidea, Micula staurophora, Prediscosphaera cretacea, Prediscosphaera ponticula, Retacapsa angustiforata, Retacapsa crenulata, Rucinolithus hayi, Tranolithus minimus, Tranolithus orionatus, Zeugrhabdotus diplogrammus, Zeugrhabdotus bicrescenticus, Watznaueria barnesae and Watznaueria manivitae. The occurrence of Aspidolithus parcus and Aspidolithus parcus constrictus allows to allocate our samples to the Aspidolithus parcus zone (CC 18) of Sissingh (1977).

Furthermore, the presence of Bukryaster hayi (Fig. 10a, b), a species with an extremely short range in the early Campanian, has been observed in a few samples. The first occurrence of this species defines the Bukryaster hayi subzone CC18b. Rare specimens of Bukryaster hayi occur above the bentonite layers at Pennapiedimonte (sample PP 

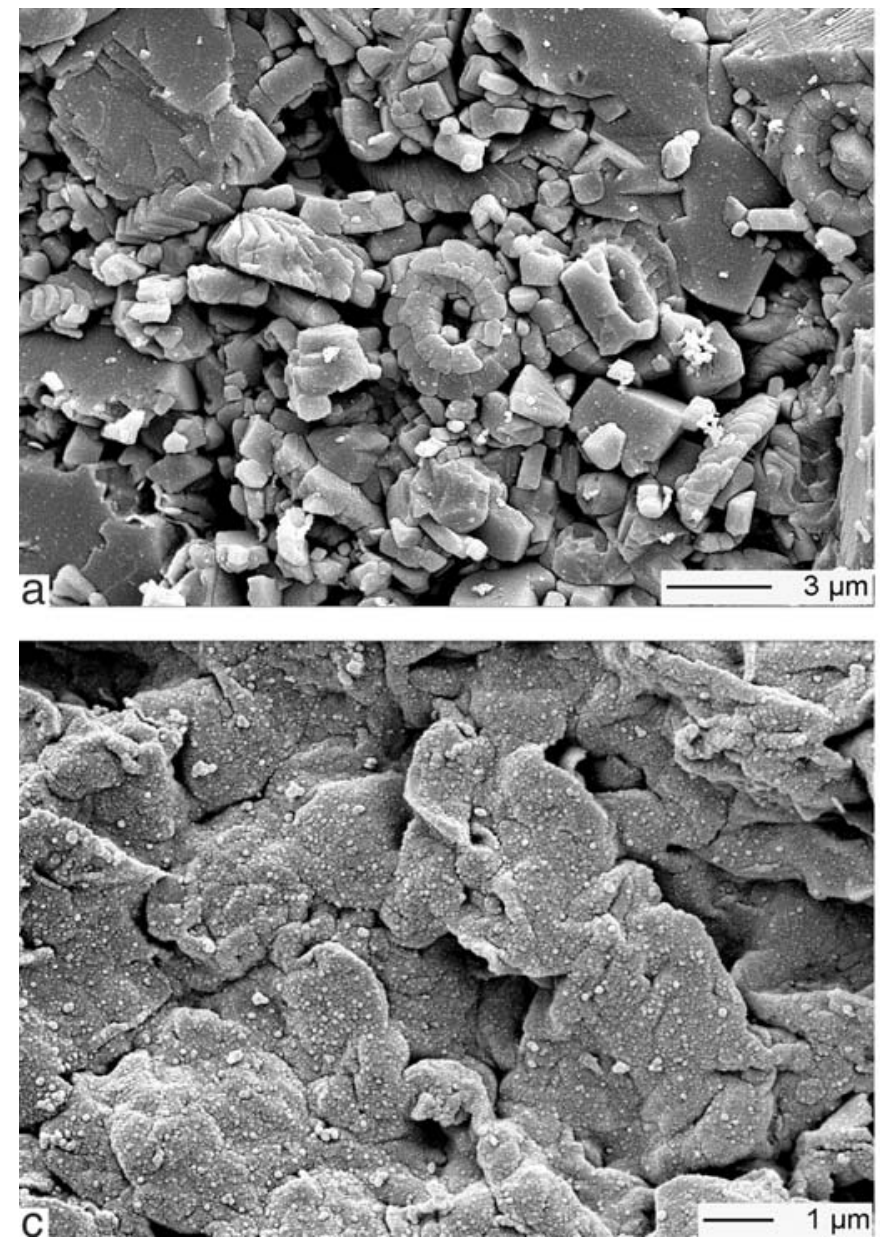

Fig. 8 Stereoscan electron micrographs of pelagic sediment and bentonites. Tre Grotte Formation, Montagna della Maiella. a Pelagic chalk of Tre Grotte Formation, composed of coccoliths overgrown by syntaxial cement and larger calcite crystals probably also resulting from overgrowth; sample PP 5. b Grains with vac-

26) and between them at Furlo (sample F7), and allow to place at least the upper ash layer in the upper part of zone CC 18.

\section{$\mathrm{U}-\mathrm{Pb}$ dating on zircons}

Sample PP-6 has a homogeneous zircon population consisting of prismatic to long-prismatic grains, or fragments thereof. Measured uranium concentrations were within a narrow range of $250-280 \mathrm{ppm}$, contrasting with largely variable thorium contents (Th/U of 0.4 to 1.2 ; Table 3 ). Four analyses consisting of 1 to 4 zircon grains each, yielded a precise ${ }^{206} \mathrm{~Pb} /{ }^{238} \mathrm{U}$ age of $81.67 \pm 0.21 \mathrm{Ma}$ at 95\% confidence level (Fig. 11). Since there are no signs of inherited cores, and possible surface-related lead loss has been minimized by mechanical abrasion, the age is interpreted as the crystallization age of volcanic zircon.

The zircons of sample F-2 show a much larger morphological variability from short- to long-prismatic, and some inherited cores were already visible in short-pris-
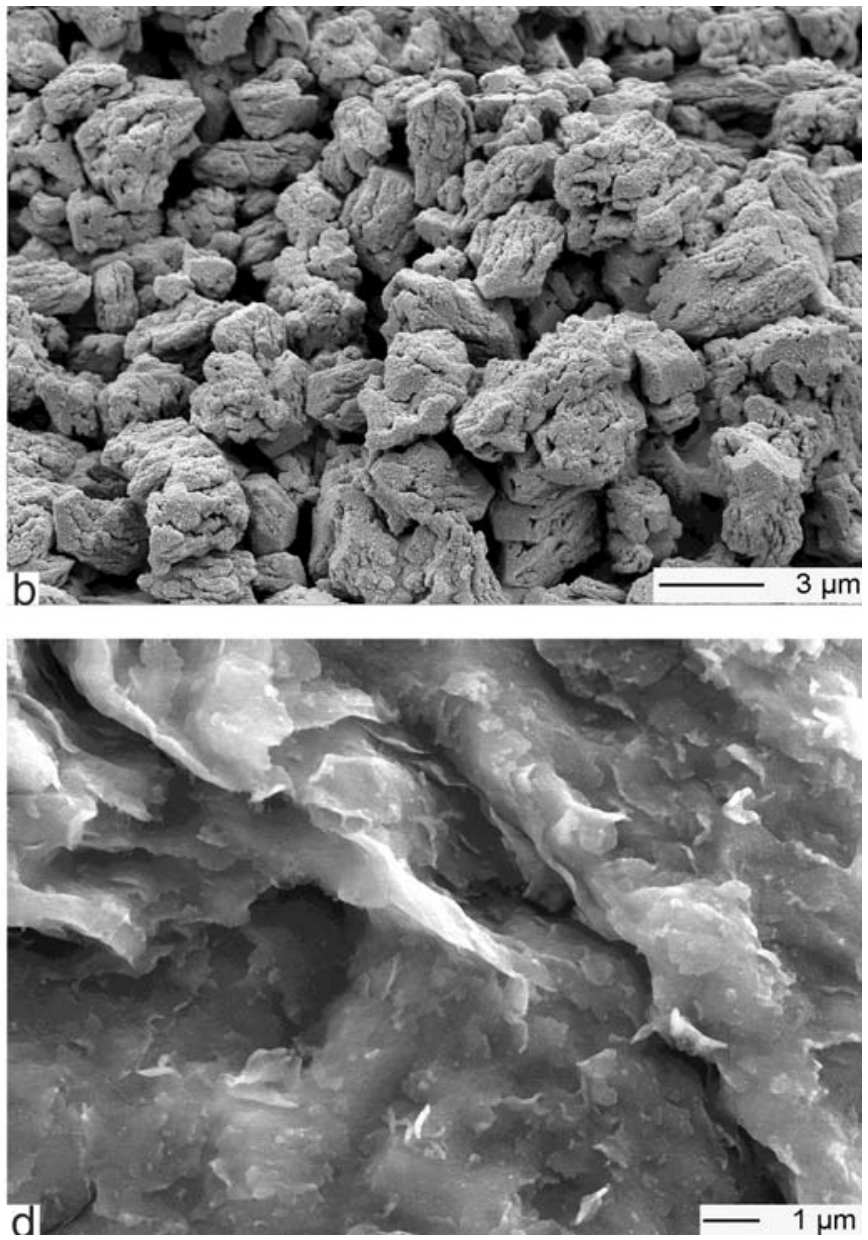

uoles, most probably glass shards, coated by clay minerals from the white clay at the base of the upper ash bed; sample PP 6. c Coalescing grains, probably glass shards; sample PP 8. d Dense mass of crenulated to flaky smectite from upper greenish grey part of lower ash bed; sample PP 8

matic zircon during optical inspection. Six microfractions of 2 to 4 grains were analysed and yielded ${ }^{206} \mathrm{~Pb} /{ }^{238} \mathrm{U}$ ages between 80.4 and 224.2 Ma (Table 3). They define a mixing line with an inherited component of $467 \pm 32 \mathrm{Ma}$ age (upper intercept), whereas the lower intercept age is $80.3 \pm 1.8 \mathrm{Ma}$ (Fig. 11b). Four out of six analyses are, however, analytically concordant between 80.4 and $81.4 \mathrm{Ma}$ (Fig. 11c). They consist of prismatic and longprismatic zircons uniquely and are thus considered to be free of inheritance. A precise crystallization age cannot be assigned to these points, but we argue that the scatter in ${ }^{206} \mathrm{~Pb} /{ }^{238} \mathrm{U}$ ages is due to post-crystallization lead loss. Analysis 6, yielding an age of $81.4 \mathrm{Ma}$, would probably approximate the crystallization age.

\section{Discussion}

The small thickness of the bentonite layers, combined with their wide lateral extent of $200 \mathrm{~km}$, the relic vitroclastic texture (Fig. 8c), the purely smectitic composition 
Fig. 9 Planktonic foraminifera from Pennapiedimonte: a-e from sample L 250.30 (approx. $1 \mathrm{~m}$ above PP8); a Globotruncanita elevata; b G. elevata; c Globotruncanita stuartiformis; d Globotruncana arca; $\mathbf{e}$ Marginotruncana pseudolinneiana. $\mathbf{f}, \mathbf{g}, \mathbf{h}$ from sample PP 7 f Globotruncana linneiana; $\mathbf{g}$ Globotruncanita elevata; $\mathbf{h}$ Rosita fornicata. Scale bar: $100 \mu \mathrm{m}$
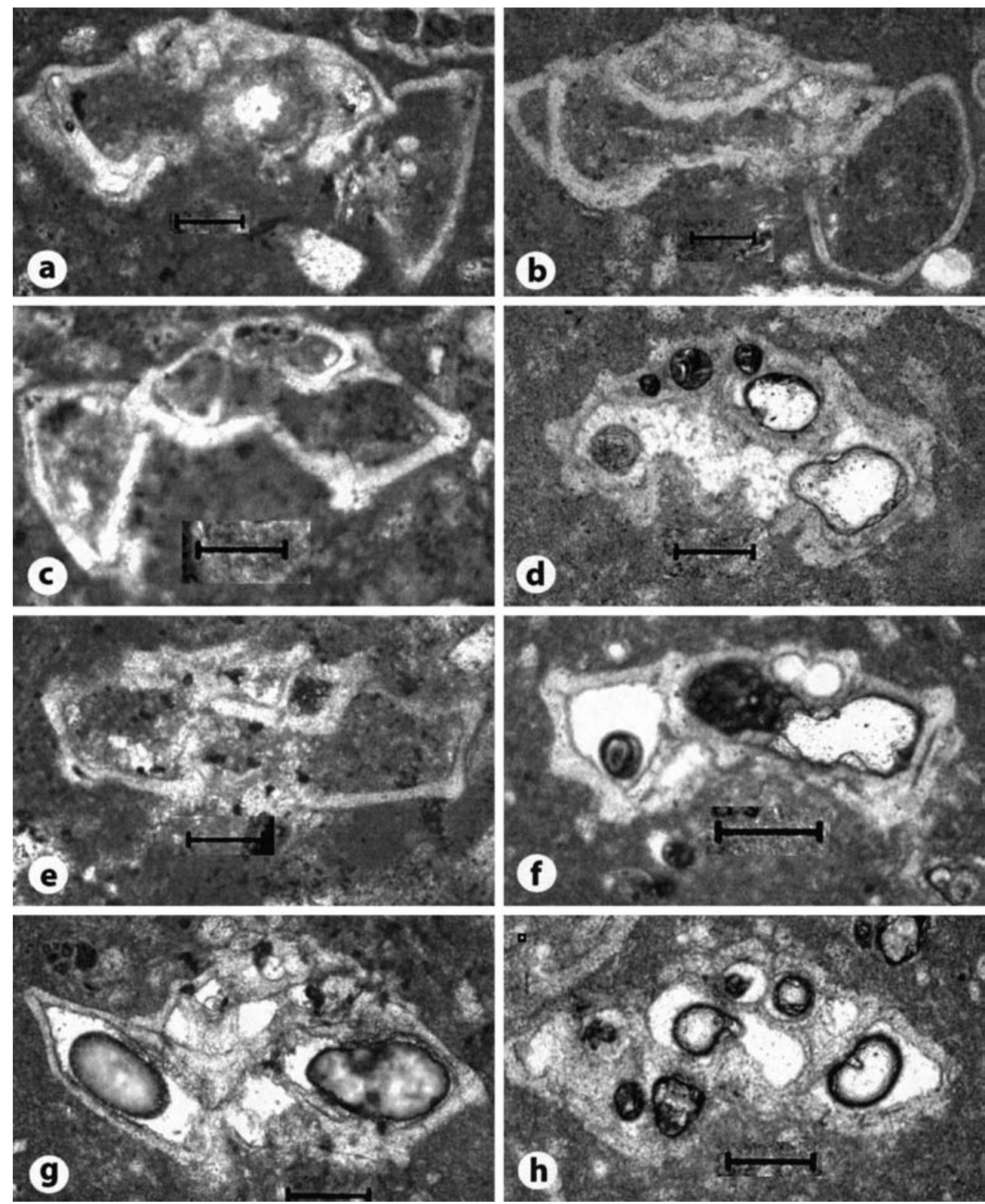

of the clay mineral assemblage that contrasts with that of the associated pelagic sediments, and the occurrence of euhedral and high-temperature mineral grains show beyond any doubt that our bentonites represent layers of wind-borne volcanic ash intercalated within the pelagic and turbiditic limestones of the host formations.

Age and correlation

In Montagna di Maiella, the pelagic limestone sequence, in which the two volcanic ash layers occur, is dated by planktonic foraminifera and nannofossils as early Campanian, Globotruncanita elevata zone and nannofossil zone CC18 of Sissingh (1977), and falls into the reversed interval of chron 33 of the palaeomagnetic time scale (Fig. 3; between 79.075 and $83 \mathrm{Ma}$ in the time scale of
Cande and Kent 1995; Lampert et al. 1997). At Furlo, the limestones enclosing the two ash layers are also dated by calcareous nannofossils as zone CC 18 and equally occur in the reversed interval of chron 33 (Fig. 3; Alvarez and Lowrie 1984; Mattias et al. 1988). The occurrence of Bukryaster hayi above the upper bentonite layer at Pennapiedimonte and below it at Furlo allows to place the upper ash layer in the upper part of zone CC 18.

In Montagna della Maiella, the two layers are separated by $4.5 \mathrm{~m}$ of pelagic and turbiditic limestones, and at Furlo by about $1 \mathrm{~m}$ of pelagic limestones without turbiditic intercalations (Fig. 4). The difference in thickness of the intervening limestones may be explained by the different sedimentation rates at the two locations, which are $8.6 \mathrm{~mm} 10^{-3}$ year for the reversed interval of chron 33 at Furlo (Alvarez and Lowrie 1984) and approximately $21 \mathrm{~mm} 10^{-3}$ year in Valle Tre Grotte (Lampert et al. 
Fig. 10 Calcareous nannofossils from Pennapiedimonte and Furlo: a, b Bukryaster hayi, a Furlo, sample F 7, b. Pennapiedimonte, sample PP26; c, d Rucinolithus hayi, c Furlo sample F1, d Furlo sample F 5; e Micula staurophora, Pennapiedimonte sample PP 26; f Prediscosphaera ponticula, Pennapiedimonte sample PP 7; g Retacapsa crenulata, Furlo sample F 1; h Cribrosphaerella ehrenbergi, Pennapiedimonte sample PP 26; i Zeugrhabdotus diplogrammus, Pennapiedimonte sample PP 23; j Tranolithus minimus Pennapiedimonte sample PP 23; k Retacapsa angustiforata, Pennapiedimonte sample PP 27; 1 Zeugrhabdotus bicrescenticus, Furlo sample F 10; m Watznaueria manivitae, Pennapiedimonte sample PP 23; n Eiffellithus turriseiffelii, Pennapiedimonte sample PP 26; o Cretarhabdus conicus, Pennapiedimonte sample PP 26; p Tranolithus orionatus, Furlo sample F10; q, r Aspidolithus parcus parcus, Pennapiedimonte sample PP 27; s Aspidolithus parcus constrictus, Pennapiedimonte sample PP 27; t Chiastozygus litterarius Pennapiedimonte sample PP 7. All images crossed nicols and same magnification; scale bar: $2 \mu \mathrm{m}$
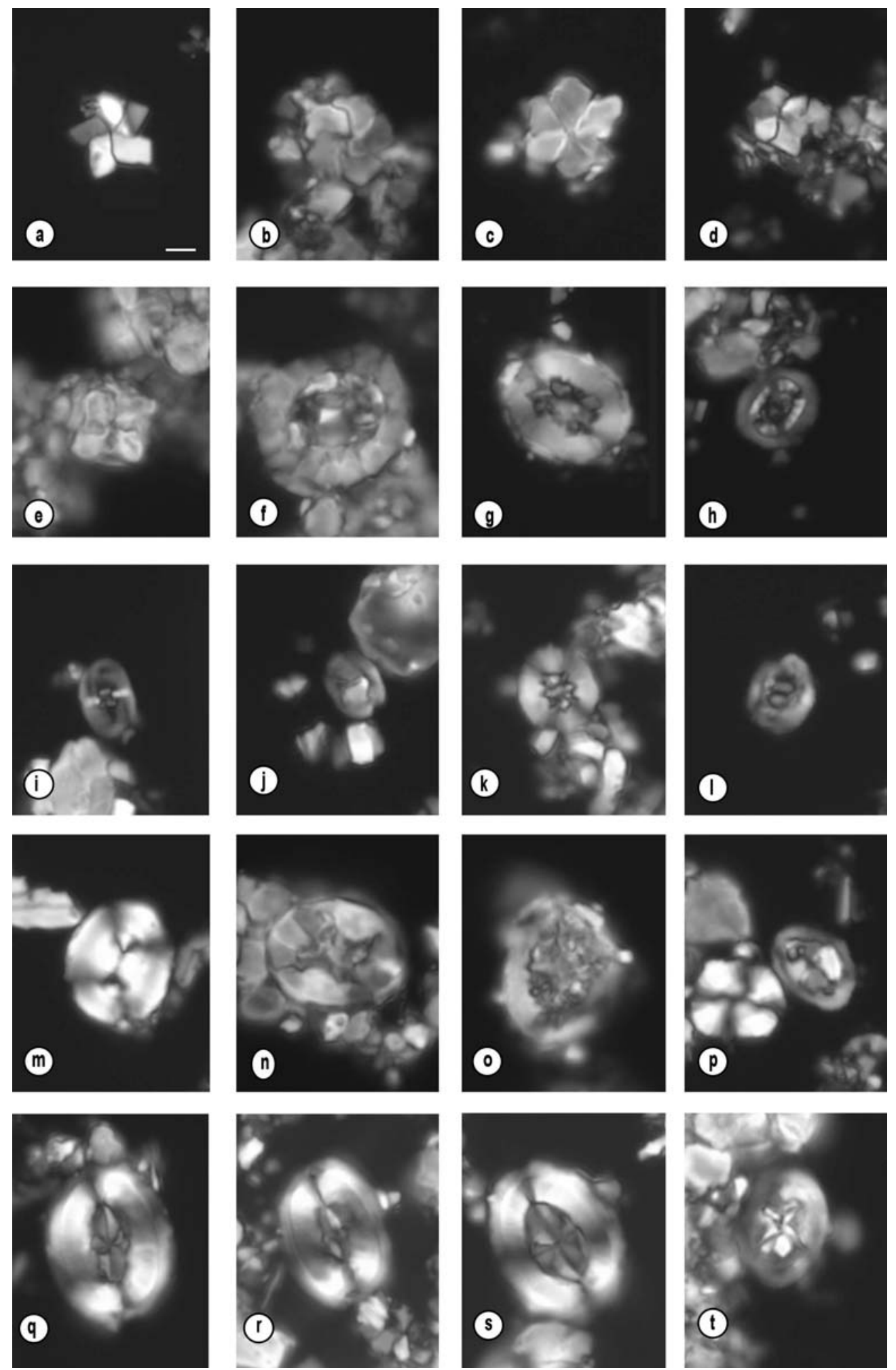

1997). Although in Montagna della Maiella fine calcisiltite, turbiditic lime mudstone/periplatform ooze and pelagic calcilutite are difficult to distinguish in the field, at least $3 \mathrm{~m}$ of the sediment between the two ash layers are redeposited, leaving no more than $1.5 \mathrm{~m}$ of pelagic sediment separating the two layers. The occurrence of two distinct layers occurring in Montagna della Maiella and at Furlo, each of nearly identical thickness and separated from each other by $1-\sim 1.5 \mathrm{~m}$ of pelagic sediment, leaves little doubt that we deal with the same horizons documenting the same volcanic events. Our correlation is supported by the-within the analytical errors-good 

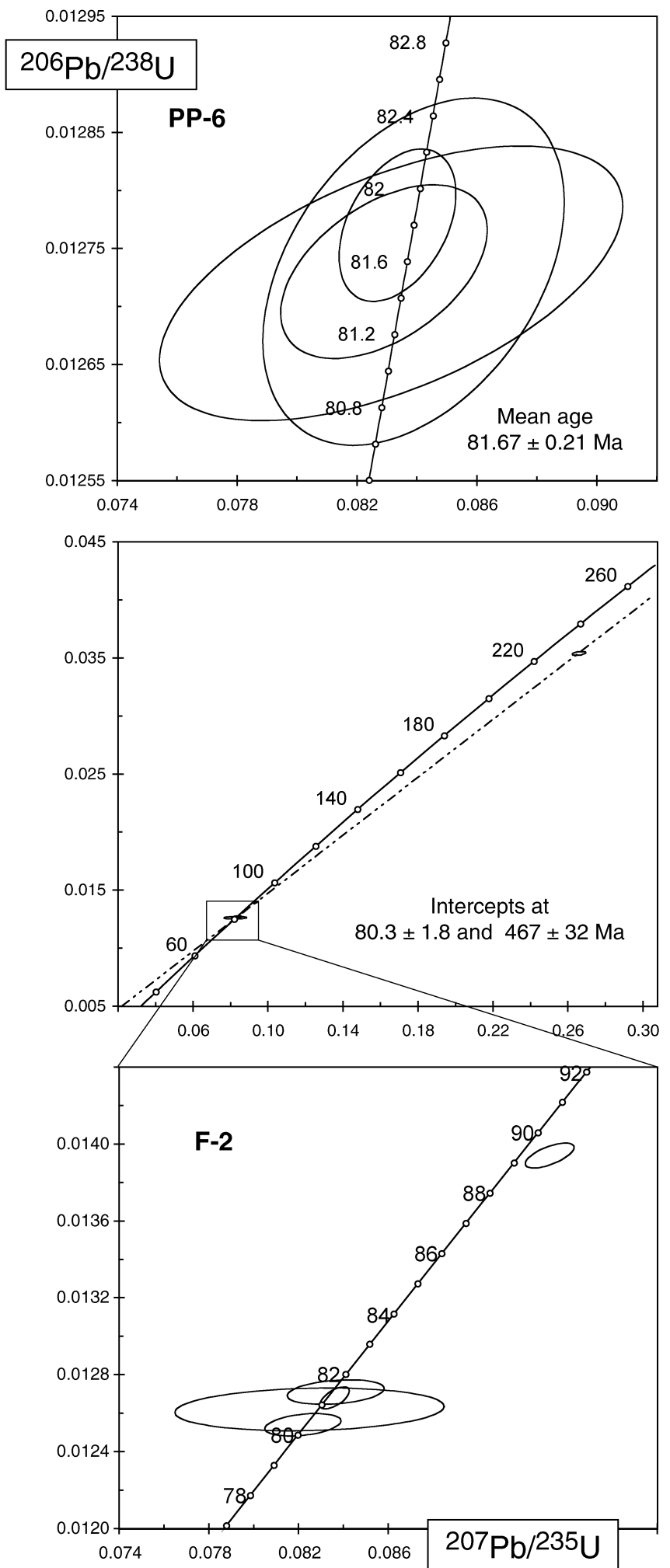

Fig. $11 \mathrm{U}-\mathrm{Pb}$ concordia diagrams for zircons of the upper bentonite layer; samples PP 6 (Pennapiedimonte) and F 2 (Gola del Furlo). Ellipses denote analytical $2 \sigma$ uncertainties correlation of the ratios of two immobile elements, $\mathrm{Al}$ and Ti. For the lower ash layer, the $\mathrm{TiO}_{2} / \mathrm{Al}_{2} \mathrm{O}_{3}$ ratios are 0.045 (PP 8) and 0.053 (F 15), respectively; for the upper ash layer they are both 0.035 . The ash layers were not (yet) observed at other locations in the external Apennines, but this may be due to poor outcrop conditions or related to local submarine current erosion or bioturbation (cf. Ninkovich et al. 1978).

Because the upper ash layers at Pennapiedimonte and at Furlo can be safely correlated and obviously are derived from the same volcanic event, their ages must be exactly the same. Indeed the crystallization age of the zircons at Pennapiedimonte $(81.67 \pm 0.21 \mathrm{Ma})$ agrees within the errors with the approximated zircon crystallization age of the zircons at Furlo (between 80.4 and 81.4 Ma).

\section{Significance of the mineral assemblage}

The sediments in which the volcanic ash layers occur obviously have not undergone important diagenetic changes as far as the clay mineral assemblage is concerned. The stratigraphic overburden is estimated to have been never more than $\pm 1,500$ to $2,000 \mathrm{~m}$, and the presence of almost pure montmorillonite in the ash layers suggests that we deal with the depositional clay mineral assemblage. The clay minerals in the host formation therefore reflect primary variations in the source areas and in the oceanic environment (Deconinck 1992). Accarie and Deconinck (1989) and Accarie et al. (1989) have investigated the geochemistry of the pelagic periplatform limestones at Montagna della Maiella and their clay-mineral assemblages, and have interpreted them in terms of long-term eustatic sea-level variations. The insoluble residues in the pelagic back-ground sediments never amount to more than $5 \mathrm{wt} \%$, and the clay mineral assemblages are dominated by smectites (40-90\%) and illite (5-40\%, Accarie et al. 1989), with minor amounts of chlorite $( \pm 5 \%)$ and the episodic occurrence of abundant palygorskite in redeposited calcarenites in the Turonian (Accarie and Deconinck 1989). The smectite/illite ratios varies from 0.5 to 13 . Also in the Marchean Apennines, smectites $(\geq 80 \%)$ and illite $(\leq 20 \%)$ dominate the clay mineral assemblage of the pelagic limestones of the lower Campanian (Deconinck 1992).

The composition of the inferred ash layers contrasts sharply with that of the pelagic and peri-platform background sediments; both layers consist entirely of smectite/ montmorillonite and are almost carbonate-free. In contrast to mixed-layer detrital illite-smectites in deep-sea sediments, authigenic smectites resulting from submarine alteration of volcanic ash are pure or nearly pure smectites (Kastner 1981). According to their structural formula, the composition of the smectites of the bentonite layers is close to that of the end-member montmorillonite, which, if the only clay mineral present, is regarded as typical for bentonitic clays derived from the devitrification and accompanying chemical alteration of glassy ig- 
neous material (Vallier and Kidd 1977). During this process, the volcanic glass undergoes hydrolysis with the addition of magnesium from sea water to give montmorillonite, and releases silica and alkali metals.

The high amount of idiomorphic zircon grains, and the occurrence of idiomorphic apatite, of titanite, rutile and hornblende are equally interpreted as volcanic signatures. Metamorphic minerals (garnet, epidote) could be derived from vent erosion during explosive volcanic activity (see e.g. Fisher and Schmincke 1984). Differences in the composition of the heavy mineral assemblages within individual ash layers, for instance in the garnet/zircon ratios in the upper ash layer, need not necessarily indicate different volcanic sources, but may reflect aeolian fractionation, i.e. differential settling of grains of different shape and density downwind (Fisher and Schmincke 1984).

\section{Source of the ash layers}

Pyroclastic material, including tephra, is typically produced by explosive eruptions of subduction-related magmatism and is an important component in marine sediments; however, minor eruptions are generally not recorded in the marine realm beyond $100 \mathrm{~km}$, except as very fine-grained disseminated material (Kennett 1981). Although alkaline intraplate and MOR-basaltic volcanics occur in the Cretaceous of peninsular Italy and Sicily (e.g. Longaretti and Rocchi 1990), indications of explosive volcanism are scarce in the Cretaceous of the Alps, the Apennines and in the western Mediterranean area. A similar ash layer, however, apparently of slightly younger age (late Campanian), has recently been described from a similar base-of-slope succession in Monte Gargano (Graziano and Addabo 1996). From Furlo and other locations, Vannucci et al. (1981) mention the presence of volcanogenic debris mixed with sediment of biogenic origin, particularly siliceous debris in the Scaglia Bianca Formation (Cenomanian) and the Livello Bonarelli (Cenomanian/Turonian boundary). However, from their description, illustrations and chemical analyses one gets the definite impression that the inferred volcanic material, if present at all, is masked by biogenic silica, and that only one horizon could be an original ash layer documenting a discrete volcanic event (their sample FU 2, Furlo, Cenomanian). In the Apennines, the only other relics of explosive volcanicity of inferred late Cretaceous age known to us are cineritic layers with a rhyolitic affinity occurring in the Cilento Flysch of the internal southern Apennines (Di Girolamo et al. 1984). The age of these ash layers is, however, rather poorly constrained and controversial.

The source of the few Cretaceous ash layers in the Apennines is unknown, and there are no data with respect to ash-fall geometry. The ash composing the bentonite beds may have been dispersed both by wind and marine currents (cf. McCoy 1980); however, as there is no evidence for redistribution of the material by currents, winddriven transport appears to be primarily responsible for the deposition of the ash. This is also suggested by the fact that the thicknesses of the two ash layers do not change over a distance of $200 \mathrm{~km}$. Volcanic ash may be transported by winds over considerable distance, whereby the bed thickness appears to decrease exponentially with distance from the volcanic source (see e.g. Fig. 3 in Ninkovich et al. 1978 and Fig. 6 in McCoy 1980). Ninkovich et al. (1966) estimated that the maximum distance from the source to which ash can be transported by wind to form a distinct layer in deep-sea sediments is about $1,000 \mathrm{~km}$, but distances much larger have been safely established (e.g. Y 5 Ischia ash in the eastern Mediterranean, McCoy 1980; >3,000 km for the Youngest Toba Tuff, $75 \mathrm{Ka}$, Shane et al. 1995) and, at a distance of approximately $1,000 \mathrm{~km}$, the (uncompacted) Youngest Toba Tuff is still about $35 \mathrm{~cm}$ thick (Ninkovich et al. 1978). In any case, the compacted thickness of 13 to $15 \mathrm{~cm}$ of the upper bentonite at both sections, Pennapiedimonte and Furlo, which are about $200 \mathrm{~km}$ apart, argues for a distant volcanic source and an extreme volcanic event. The fine grain size of the ash is consistent with a distant source (Fisher 1964).

Although convergent movements in the Alpine belt are documented for the late Cretaceous by flysch deposits and exhumed Cretaceous high-pressure metamorphic mineral assemblages, traces of coeval subduction-related volcanicity are conspicuously scarce in the western Mediterranean area. Bentonites from possibly andesitic sources occur in the upper Maastrichtian portion of the south-Pennine Gurnigel Flysch of the central Alps (Winkler et al. 1985); also, in this case, the source is unknown. In north-eastern Croatia, however, granitoids occur that were radiometrically dated as late Cretaceous to early Paleocene (72$61 \mathrm{Ma}$, Pamic et al. 1989; Pamic 1993) and that document a subduction-related magmatic belt active from middle Cretaceous to early Palaeogene (Pamic 2002). The radiometrically dated granitoids are $\sim 10$ million years younger than our ash layers, but from the same area, "basalts, rhyolites and tuffs" are reported to be intercalated with Upper Cretaceous deep-water clastics and limestones (Pamic et al. 1989; Pamic 1993).

In many cases, the areal extent and distribution of wind-borne volcanic ash layers reflect the wind pattern of the high troposphere at the time of deposition (e.g. McCoy 1980; Kennett 1981, his Fig. 10; Elder 1988). In late Cretaceous times, the area of the Maiella platform margin was situated between 20 and $30^{\circ} \mathrm{N}$ (Scotese et al. 1989, cf. Fig. 18.2 in Bernoulli 2001). Palaeoclimatic models (Barron and Washington 1982) postulate a zonal climate for that time. This would place the external Apennines in an area with prevailing north-easterly trade winds. Such a wind pattern is compatible with the direction of platform progradation along the margins of the Apulian carbonate platform. Indeed, the north-eastern margin of the Apulian platform is non-progradational (De Alteriis and Aiello 1993) and, therefore, is expected to be a windward margin (cf. Eberli and Ginsburg 1989; Schlager 1993), whereas late Cretaceous progradation in the Maiella margin appears to be directed towards the 
north-west and west (Mutti et al. 1996). A north-easterly or easterly provenance of the wind-borne material is thus possible. A provenance of the ash layers from the magmatic province of the Dinarides would be compatible with possible transport distances $(<1,500 \mathrm{~km}$ palinspastically), the inferred wind pattern, the type of volcanicity and the geodynamic setting.

The inherited component of Ordovician age (467 \pm $23 \mathrm{Ma}$ ) in zircons from Furlo documents recycling of zircons from older crustal rocks. Granitoids of this age (480-440 Ma) occur in the Adriatic crust of the southern Alps (Boriani et al. 1982/83; Ragettli 1993) and are interpreted as the relics of an Ordovician arc or fore-arc complex overprinted during the Variscan orogeny (Handy et al. 1999). The areal extent of these granitoids in the Variscan crust of the south-Tethyan margin, however, is not known, but they could extend into the presumed source areas of the ash layers.

\section{A numerical age for the early Campanian}

The zircon crystallization age of $81.67 \mathrm{Ma}$ falls within the time span of the reversed interval of chron 33 of the palaeomagnetic time scale of Cande and Kent (1995; between 79.075 and $83 \mathrm{Ma}$ ) and within the early Campanian in the time scale of Obradovich (1993, and in Gradstein et al. 1994, 1995). Therefore, we have no reasons to doubt that the $81.4 \mathrm{Ma}$ represent the date of volcanic extrusion and sedimentation of the ash layer. Our high precision $\mathrm{U} / \mathrm{Pb}$ date, therefore, complements and confirms the ${ }^{40} \mathrm{Ar} /{ }^{39} \mathrm{Ar}$ laser-fusion dates of Obradovich (1993) who gives an age of $81.71 \pm 0.34$ for the early Campanian Scaphites hippocrepis II zone, and of 80.54 $0.55 \mathrm{Ma}$ for the Baculites obtusus zone of the early middle Campanian.

The Aspidolithus parcus zone (CC 18), the nannofloral age of the ash layers, overlaps with the upper part of the Globotruncanita elevata zone. At Pennapiedimonte, the ash layers occur about in the middle of the Globotruncanita elevata zone, which coincides with the reversed interval of chron 33, at Furlo slightly below the middle of the chron. More specifically, the radiometrically dated (upper) ash layer falls within the upper part of the Aspidolithus parcus zone (CC 18). Our radiometric age of 81.67 Ma, therefore, approximately dates the middle of C33r.

\section{Conclusions}

The lithology and the clay mineral assemblage of the two bentonite layers at Montagna della Maiella and Gola del Furlo contrast sharply with those of the enclosing pelagic and turbiditic sediments. The purely montmorillonitic composition of the bentonites and the lack of 'normal' pelagic sediment in them leave little doubt about our interpretation as wind-borne ash deposits. The close chronological correlation between the two sections suggests that the ash layers document the same extreme volcanic events, which, in view of the constant thickness of the ash layers over $200 \mathrm{~km}$, must have occurred at a great distance, possibly near the subduction zone of the Vardar Ocean in the Dinarides. Bio- and magnetostratigraphy date these events to the middle part of the early Campanian Globotruncanita elevata zone, which coincides approximately with the reversed interval of chron 33.

Our high precision $\mathrm{U} / \mathrm{Pb}$ age determination on zircons date the middle of the reversed interval of chron 33 and of the Globotruncanita elevata zone at $81 \mathrm{Ma}$. We suspect that ash beds related to explosive volcanicity are much more frequent in the Tethyan deep-sea record than usually thought and that in most cases have not been recognized as such or were simply overlooked. If this is the case, there exists a potential for establishing a high-precision chronology of the pelagic Tethyan successions.

Acknowledgements Field work of D.B. was supported by the Swiss National Science Foundation (grant 20-45131.95). D.B. acknowledges the help of Gregor Eberli, Maria Mutti and Iwan Stössel in the field. We thank Alberto Castellarin, Carlo Doglioni, Gregor Eberli, Bill Lowrie, Maria Mutti, Jakob Pamic and Livio Vezzani for much information and discussion, Wilfried Winkler for heavy mineral analysis, and Silke Voigt and Igor Villa for thoughtful reviews. M.F. and W.S. acknowledge the help of Sébastien Potel for clay mineral dressing and Heinz Hürlimann for combustion analysis. D.B. thanks Richard Guggenheim, Marcel Düggelin and Daniel Mathys for their cooperation with scanning electronic microscopy and Urs Gerber for much help in the preparation of the illustrations. The technical help during $\mathrm{U}-\mathrm{Pb}$ analysis at ETH Zürich of Irene Ivanov and Albrecht von Quadt is kindly acknowledged.

\section{References}

Accarie H (1988) Dynamique sédimentaire et structurale au passage platforme/bassin. Les faciès crétacés et tertiaires-massif de la Maiella (Abruzzes, Italie). Ecoles des Mines de Paris, Mém Sci Terre, no 5

Accarie H, Deconinck JF (1989) Relations entre présence de palygorskite et périodes d'anoxie à l'Albien supérieur et au Turonien inférieur à moyen dans le massif de la Maiella (Abruzzes, Italie). C R Acad Sci Paris. 308(II):1267-1272

Accarie H, Renard M, Deconinck JF, Beaudoin B, Fleury JJ (1989) Géochimie des carbonates (Mn, Sr) et minéralogie des argiles de calcaires pélagiques sénoniens. Relations avec les variations eustatiques (Massif de la Maiella, Abruzzes, Italie). C R Acad Sci Paris 309(II):1679-1685

Alvarez W, Lowrie W (1984) Magnetic stratigraphy applied to synsedimentary slumps, turbidites and basin analysis: the Scaglia limestones at Furlo (Italy). Geol Soc Am Bull 95:324-336

Bally AW, Burbi L, Cooper C, Ghelardoni R (1986) Balanced sections and seismic reflection profiles across the central Apennines. Mem Soc Geol It 35:257-310

Barron EJ, Washington WM (1982) Cretaceous climate - a comparison of atmospheric simulations with the geological record. Palaeogeogr Palaeoclimat Palaeoecol 40:103-133

Bernoulli D (1972) North Atlantic and Mediterranean Mesozoic facies, a comparison. In: Hollister CD, Ewing JI et al. (eds) Initial Reports of the Deep Sea Drilling Project 11. Government Printing Office, Washington, DC, pp 801-871

Bernoulli D (2001) Mesozoic-Early Tertiary carbonate platforms, slopes and basins of the external Apennines and Sicily. In: Vai GB, Martini P (eds) The Apennines, geology of a mountain chain. Kluwer, Dordrecht, pp 307-326 
Bernoulli D, Peters T (1970) Traces of rhyolitic-trachytic volcanism in the Upper Jurassic of the Southern Alps. Eclogae Geol Helv 63:609-621

Bernoulli D, Peters T (1974) Traces of rhyolitic-trachytic volcanism in the Upper Jurassic of the Southern Alps: reply. Eclogae Geol Helv 67:207-213

Bernoulli D, Kälin O, Patacca, E (1979) A sunken continental margin of the Mesozoic Tethys: the northern and central Apennines. In: Purser BH, Beaudoin B (eds) Symposium 'Sédimentation Jurassique W Européen'. Assoc Sédiment Franç Publ Spéc 1:197-210

Bice D, Stewart KG (1990) The formation and drowning of carbonate seamounts: tectonic and ecological controls in the northern Apennines. In: Tucker ME, Wilson JL, Crevello PD, Sarg JR, Read JF (eds) Carbonate platforms, facies, sequences and evolution. Int Assoc Sediment Spec Publ 9:145-168

Boriani A, Origoni Giobbi E, Del Moro A (1982/83) Composition, level of intrusion and age of the 'Serie dei Laghi' orthogneisses (northern Italy-Ticino, Switzerland). Rend Soc It Mineral Petrol 38:191-205

Cande SC, Kent DV (1995), Revised calibration of the geomagnetic polarity timescale for the Late Cretaceous and Cenozoic. J Geophys Res 100:6093-6095

Carta Geologica d'Italia (1952) $\mathrm{F}^{\mathrm{O}}$ 116: Gubbio, 1:100 000. Servizio Geologico d'Italia, Roma

Carta Geologica d'Italia (1970) $\mathrm{F}^{\mathrm{o}}$ 147: Lanciano, 1:100,000. Servizio Geologico d'Italia, Roma

Crescenti U, Crostella A, Donzelli G, Raffi G (1969) Stratigrafia della serie calcarea dal Lias al Miocene nella regione marchigiana-abruzzese (Parte II - Litostratigrafia, biostratigrafia, paleogeografia). Mem Soc Geol It 8:343-420

De Alteriis G, Aiello G (1993) Stratigraphy and tectonics offshore Puglia (Italy, southern Adriatic Sea). Mar Geol 113:233-253

Deconinck JF (1992) Sédimentologie des argiles dans le JurassiqueCrétacé d'Europe occidentale et du Maroc. Mémoire présenté à l'Université des Sciences et Technologies de Lille pour obtenir l'habilitation à diriger des recherches en sciences naturelles

Deconinck JF, Bernoulli D (1991) Clay mineral assemblages of Mesozoic pelagic and flysch sediments of the Lombardian Basin (Southern Alps): implications for paleotectonics, paleoclimate and diagenesis. Geol Rundsch 80:1-17

Di Girolamo P, Ietto A, Nardi G, Pappone G (1984) Livelli cineritici nel flysch del Cilento (sud Italia). Pubbl Dipart Sci Terra, Univ Napoli

Eberli GP, Ginsburg RN (1989) Cenozoic progradation of Northwestern Great Bahama Banks, a record of lateral platform growth and sea-level fluctuations. In: Crevello PD, Wilson JL, Sarg JF, Read JF (eds) Controls on carbonate platform and basin development. Soc Econ Mineral Paleontol Spec Publ 44:339-351

Eberli GP, Bernoulli D, Sanders D, Vecsei A (1993) From aggradation to progradation: The Maiella Platform, Abruzzi, Italy. In: Simo T, Scott RW, Masse JP (eds) Cretaceous carbonate platforms. Am Assoc Petrol Geol Mem 56:213-232

Eberli GP, Anselmetti FS, Betzler C, van Konijnenburg JH, Bernoulli D (2004) Carbonate platform to basin transition on seismic data and in outcrop: Great Bahama Bank and the Maiella platform margin, Italy. Am Assoc Petroleum Geol Mem (in press)

Elder WP (1988) Geometry of Upper Cretaceous bentonite beds: implications about volcanic source areas and paleowind patterns, western interior, United States. Geology 16:835-838

Fisher RV (1964) Maximum size, median diameter, and sorting of tephra. J Geophys Res 69:341-355

Fisher RV, Schmincke HU (1984) Pyroclastic rocks. Springer, Berlin Heidelberg New York

Ghisetti F, Vezzani L (1983) Deformazioni pellicolari mioceniche e plioceniche nei domini strutturali esterni dell'Appennino centro-meridionale (Maiella ed Arco Morrone-Gran Sasso). Mem Soc Geol It 26:563-577
Gradstein FM, Agterberg FP, Ogg, JG, Hardenbol J, Van Veen P, Thierry J, Huang Z (1994) A Mesozoic time scale. J Geophys Res 99:24051-24075

Gradstein FM, Agterberg FP, Ogg JG, Hardenbol J, Van Veen P, Thierry J, Huang Z (1995) A Triassic, Jurassic and Cretaceous time scale. In: Berggren WA, Kent DV, Aubry MP, Hardenbol JJ (eds) Geochronology, time scales and geochronological correlation. Soc Econ Paleontol Mineral Spec Publ 54:95-126

Graziano R, Adabbo MR (1996) Segnalazione di un livello cineritico nella serie di scarpata senoniana del Gargano meridionale. Boll Soc Geol It 115:459-466

Handy MR, Franz L, Heller F, Janott B, Zurbriggen R (1999) Multistage accretion and exhumation of the continental crust (Ivrea crustal section, Italy and Switzerland). Tectonics 18: $1154-1177$

Jenkyns HC, Gale AS, Corfield RM (1994) Carbon- and oxygenisotope stratigraphy of the English Chalk and Italian Scaglia and its paleoclimatic significance. Geol Mag 131:1-34

Jenkyns HC, Jones CE, Gröcke DR, Hesselbo SB, Parkinson DN (2002) Chemostratigraphy of the Jurassic System: applications, limitations and implications for palaeoceanography. J Geol Soc Lond 159:351-378

Kastner M (1981) Authigenic silicates in deep-sea sediments: formation and diagenesis. In: Emiliani $\mathrm{C}$ (ed) The oceanic lithosphere. The sea, vol 8. Wiley, New York, pp 916-980

Kennett JP (1981) Marine tephrochronology. In: Emiliani C (ed) The oceanic lithosphere. The sea, vol 8. Wiley, New York, pp 1373-1436

Lampert SA, Lowrie W, Hirt AM, Bernoulli D, Mutti M (1997) Magnetic and sequence stratigraphy of redeposited Upper Cretaceous limestones in the Montagna della Maiella, Abruzzi, Italy. Earth Planet Sci Lett 150:79-93

Laviano R, Melidoro A (1994) Mineralogia e chimismo delle bentoniti di Santa Croce di Magliano (CB). Geol Appl Idrogeol (Bari) 29:63-75

Longaretti G, Rocchi S (1990) Il magmatismo dell'avampaese Ibleo (Sicilia orientale) tra il Trias e il Quaternario: dati stratigrafici e petrografici di sottosuolo. Mem Soc Geol It 45:911-925

Mattias P, Montanari A, Ristori GC, Paris E (1988) Segnalazione di un livello bentonitico nella Scaglia Rossa Campaniana Cretacica presso la Gola del Furlo nell'Appennino Marchigiano (Acqualagna, Pesaro). Mineral Petrogr Acta 31:243-258

McCoy FM (1980) The upper Thera (Minoan) ash in deep-sea sediments: distribution and comparison with other ash layers. In: Doumas C (ed) Thera and the ancient world II. London, pp 57-78

Montanari A, Chan LS, Alvarez W (1989) Synsedimentary tectonics in the late Cretaceous-early Tertiary pelagic basin of the northern Apennines, Italy. In: Crevello PD, Wilson JL, Sarg JF, Read JF (eds) Controls on carbonate platform and basin development. Soc Econ Mineral Paleontol Spec Publ 44:379-399

Mostardini G, Merlini S (1988) L'Appennino centro-merdionale. Sezioni geologiche e proposta di modello strutturale. Mem Soc Geol It 35:177-202

Mutti M, Bernoulli D, Eberli GP, Vecsei A (1996) Depositional geometries and facies associations in a Upper Cretaceous prograding carbonate platform margin (Orfento Supersequence, Maiella, Italy). J Sediment Res B66:749-765

Newman ACD (ed) (1987) Chemistry of clays and clay minerals. Mineral Soc Monogr 6. Longman, London

Ninkovich D, Opdyke N, Heezen BC, Foster JH (1966) Paleomagnetic stratigraphy, rates of deposition and tephrachronology in North Pacific deep-sea sediments. Earth Planet Sci Lett 1:476-492

Ninkovich D, Sparks RSJ, Ledbetter MT (1978) The exceptional magnitude and intensity of the Toba eruption, Sumatra: an example of the use of deep-sea tephra layers as a geological tool. Bull Volcanol 41:286-298

Obradovich JD (1993) A Cretaceous time scale. In: Caldwell WGE, Kauffman EG (eds) Evolution of the Western Interior Basin. Geol Assoc Can Spec Pap 39:379-396 
Pamic J (1993) Eoalpine to Neoalpine magmatic and metamorphic processes in the northwestern Vardar Zone, the easternmost Periadriatic Zone and the southwestern Pannonian basin. Tectonophysics 226:503-518

Pamic J (2002) The Sava-Vardar Zone of the Dinarides and Hellenides versus the Vardar Ocean. Eclogae Geol Helv 95:99-113

Pamic J, Injuk J, Jaksic M (1989) Some geochemical features of the Upper Cretaceous bimodal volcanic association from the Pozeska Gora Mt. in Slavonija (northern Croatia, Yugoslavia). Geologija (Ljubljana) 31/32:415-435.

Petrova TV, Ferreiro-Mählmann R, Stern WB, Frey M (2002) Application of combustion and TGA-DTA analysis to the study of metamorphic organic matter. Schweiz Mineral Petrogr Mitt $82: 33-53$

Premoli Silva I, Sliter WV (1994) Cretaceous planktonic foraminiferal biostratigraphy and evolutionary trends from the Bottaccione section, Gubbio, Italy. Palaeontogr It 82:1-89

Ragettli RA (1993) Vergleichende U-Xe und U-Pb Datierung an Zirkon und Monazit. PhD Thesis, Eidgenössische Technische Hochschule Zürich, Switzerland

Robaszynski F, Caron M (1995) Foraminifères planctoniques du Crétacé: commentaire de la zonation Europe-Méditerranée. Bull Soc Géol France 166:681-692

Schlager W (1993) Accommodation and supply - a dual control on stratigraphic sequences. Sediment Geol 86:111-136

Scotese CR, Gahagan LM, Larson RL (1989) Plate tectonic reconstructions of the Cretaceous and Cenozoic ocean basins. Tectonophysics 155:27-48

Shane P, Westgate J, Williams M, Korisettar R (1995) New geochemical evidence for the Youngest Toba Tuff in India. Quaternary Res 44:200-204

Sissingh W (1977) Biostratigraphy of Cretaceous calcareous nannoplankton. Geol Mijnbouw 57:443-440

Stacey JS, Kramers JD (1975) Approximation of terrestrial lead isotope evolution by a two-stage model. Earth Planet Sci Lett 26:207-221
Stern WB, Mullis J, Rahn M, Frey M (1991) Deconvolution of the first basal 'illite' reflection. Schweiz Mineral Petrogr Mitt 71:453-462

Vallier TL, Kidd RB (1977) Volcanogenic sediments in the Indian Ocean. In: Heirtzler JR, Bolli HM, Davies TA, Saunders JB, Sclater JG (eds) Indian Ocean geology and biostratigraphy. Am Geophys Union, Washington, DC, pp 87-118

Van Konijnenburg J-H, Bernoulli D, Mutti M (1999) Stratigraphic architecture of a Lower Cretaceous-Lower Tertiary carbonate base-of-slope succession: Gran Sasso d'Italia (central Apennines, Italy). In: Harris PM, Saller A, Simo A, Handford R (eds) Advances in carbonate sequence stratigraphy - applications to reservoirs, outcrops and models. Soc Econ Paleontol Mineral Spec Publ 63:291-315

Vannucci S, Vannucci R, Franchi R, Mazzucotelli A (1981) Presenza di livelli vulcanoclastici al tetto della Scaglia Bianca umbro-marchigiana. Rend Soc It Mineral Petrol 37:105-131

Vecsei A (1991) Aggradation und Progradation eines Karbonatplattform-Randes: Kreide bis Mittleres Tertiär der Montagna della Maiella, Abruzzen. Mitt Geol Inst Eidgenössische Tech Hochsch Univ Zürich NF 294

Vecsei A, Sanders DGK, Bernoulli D, Eberli GP, Pignatti JS (1998) Evolution and sequence stratigraphy of the Maiella carbonate platform margin, Late Jurassic to Miocene, Italy. In: De Graciansky PC, Hardenbol J, Jacquin T, Vail PR, Farley MB (eds) Mesozoic and Cenozoic sequence stratigraphy of Western European basins. Soc Econ Paleontol Mineral Spec Publ 60:5374

Weissert H (1989) C-isotope stratigraphy, a monitor of paleooceanographic change: a case study from the Early Cretaceous. Surv Geophys 10:1-61

Welton JE (1984) SEM Petrology Atlas. Am Assoc Petrol Geol, Methods Explor Ser 4

Winkler W, Galetti G, Maggetti M (1985) Bentonite im Gurnigel-, Schlieren- und Wägital-Flysch: Mineralogie, Chemismus, Herkunft. Eclogae Geol Helv 78:545-564 